\title{
Spatial variation of $\mathrm{PM}_{2.5}, \mathrm{PM}_{10}, \mathrm{PM}_{2.5}$ absorbance and $\mathrm{PM}_{\text {coarse }}$ concentrations between and within 20 European study areas and the relationship with $\mathrm{NO}_{2}$ - Results of the ESCAPE project
}

Marloes Eeftens ${ }^{\mathrm{a}, *}$, Ming-Yi Tsai ${ }^{\mathrm{b}, \mathrm{c}, \mathrm{d}}$, Christophe Ampe ${ }^{\mathrm{e}}$, Bernhard Anwander ${ }^{\mathrm{f}}$, Rob Beelen ${ }^{\mathrm{a}}$, Tom Bellander ${ }^{\mathrm{g}}$, Giulia Cesaroni ${ }^{\mathrm{h}}$, Marta Cirach ${ }^{\mathrm{i}, \mathrm{j}, \mathrm{k}}$, Josef Cyrys ${ }^{\mathrm{l}, \mathrm{dd}}$, Kees de Hoogh ${ }^{\mathrm{m}}$, Audrey De Nazelle ${ }^{\mathrm{i}, \mathrm{j}, \mathrm{k}}$, Frank de Vocht ${ }^{\mathrm{n}}$, Christophe Declercq ${ }^{\mathrm{o}}$, Audrius Dedele ${ }^{\mathrm{p}}$, Kirsten Eriksen ${ }^{\mathrm{q}}$, Claudia Galassi ${ }^{r}$, Regina Gražulevičienè ${ }^{p}$, Georgios Grivas ${ }^{\text {s }}$, Joachim Heinrich ${ }^{\text {l,ff }}$, Barbara Hoffmann ${ }^{\text {t,ee }}$, Minas Iakovides ${ }^{\mathrm{u}}$, Alex Ineichen ${ }^{\text {b,c }}$, Klea Katsouyanni ${ }^{\mathrm{v}}$, Michal Korek ${ }^{\mathrm{g}}$, Ursula Krämer ${ }^{\mathrm{t}}$, Thomas Kuhlbusch ${ }^{\mathrm{w}}$, Timo Lanki ${ }^{\mathrm{x}}$, Christian Madsen ${ }^{\mathrm{y}}$, Kees Meliefste ${ }^{\mathrm{a}}$, Anna Mölter ${ }^{\mathrm{n}}$, Gioia Mosler ${ }^{\mathrm{m}}$, Mark Nieuwenhuijsen ${ }^{\mathrm{i}, \mathrm{j}, \mathrm{k}}$, Marieke Oldenwening ${ }^{\mathrm{a}}$, Arto Pennanen ${ }^{\mathrm{x}}$, Nicole Probst-Hensch ${ }^{\mathrm{b}, \mathrm{c}}$, Ulrich Quass $^{\mathrm{w}}$, Ole Raaschou-Nielsen ${ }^{\mathrm{q}}$, Andrea Ranzi ${ }^{\mathrm{z}}$, Euripides Stephanou ${ }^{\mathrm{u}}$, Dorothee Sugiri ${ }^{\mathrm{t}}$, Orsolya Udvardy $^{\text {aa }}$, Éva Vaskövi ${ }^{\text {aa }}$, Gudrun Weinmayr ${ }^{\text {t,bb }}$, Bert Brunekreef ${ }^{\text {a,cc }}$, Gerard Hoek $^{\text {a }}$

\footnotetext{
a Institute for Risk Assessment Sciences, Utrecht University, P.O. Box 80178, 3508 TD Utrecht, The Netherlands

${ }^{\mathrm{b}}$ Department of Epidemiology and Public Health, Swiss Tropical \& Public Health Institute, Basel, Switzerland

${ }^{\mathrm{c}}$ University of Basel, Basel, Switzerland

${ }^{\mathrm{d}}$ Department of Environmental E' Occupational Health Sciences, University of Washington, Seattle, USA

e AIRPARIF, Paris, France

${ }^{\mathrm{f}}$ Institut für Umwelt und Lebensmittelsicherheit des Landes Vorarlberg, Bregenz, Austria

${ }^{\mathrm{g}}$ Institute of Environmental Medicine, Stockholm, Sweden

${ }^{\mathrm{h}}$ Epidemiology Department, Lazio Regional Health Service, Rome, Italy

${ }^{\mathrm{i}}$ Center for Research in Environmental Epidemiology (CREAL), Barcelona, Spain

IMIM (Hospital del Mar Research Institute), Barcelona, Spain

${ }^{\mathrm{k}}$ CIBER Epidemiología y Salud Pública (CIBERESP), Spain

${ }^{1}$ HMGU Institute of Epidemiology II, Neuherberg, Germany

${ }^{\mathrm{m}}$ MRC-HPA Centre for Environment and Health, Department of Epidemiology and Biostatistics, Imperial College London, London, United Kingdom

${ }^{\mathrm{n}}$ Centre for Occupational and Environmental Health, The University of Manchester, Manchester, England, United Kingdom

${ }^{\circ}$ French Institute for Public Health Surveillance (InVS), Saint-Maurice Cedex, France

${ }^{\mathrm{p}}$ Vytautas Magnus University, Kaunas, Lithuania

${ }^{\mathrm{q}}$ Danish Cancer Society Research Center, Copenhagen, Denmark

${ }^{\mathrm{r}}$ AOU San Giovanni Battista - CPO Piedmont, Turin, Italy

${ }^{\mathrm{s}}$ School of Chemical Engineering, National Technical University of Athens, Greece

${ }^{\mathrm{t}}$ IUF Leibniz Research Institute for Environmental Medicine, University of Düsseldorf, Düsseldorf, Germany

${ }^{\mathrm{u}}$ Environmental Chemical Processes Laboratory, Department of Chemistry, University of Crete, Heraklion, Greece

${ }^{v}$ Department of Hygiene, Epidemiology \& Medical Statistics, Medical School, National and Kapodistrian University of Athens, Greece

${ }^{\mathrm{w}}$ Air Quality \&' Sustainable Nanotechnology, IUTA Institut für Energie- und Umwelttechnik, Duisburg, Germany

${ }^{\mathrm{x}}$ Department of Environmental Health, National Institute for Health and Welfare (THL), Kuopio, Finland

${ }^{\mathrm{y}}$ Division of Epidemiology, Norwegian Institute of Public Health, Oslo, Norway

${ }^{\mathrm{z}}$ Regional Reference Centre on Environment and Health, ARPA Emilia Romagna, Modena, Italy

${ }^{\text {aa }}$ Department of Air Hygiene, National Institute of Environmental Health, Budapest, Hungary

$\mathrm{bb}$ Institute of Epidemiology and Medical Biometry, Ulm University, Ulm, Germany

${ }^{\mathrm{cc}}$ Julius Center for Health Sciences and Primary Care, University Medical Center Utrecht, Utrecht, The Netherlands

dd University of Augsburg, Environmental Science Center, Augsburg, Germany

ee Medical Faculty, Heinrich-Heine University of Düsseldorf, Düsseldorf, Germany

${ }^{\mathrm{ff}}$ HMGU Institute of Epidemiology I, Neuherberg, Germany
}

\footnotetext{
Abbreviations: CV, coefficient of variation; ESCAPE, European Study of Cohort for Air Pollution Effects; GIS, Geographic Information Systems; LUR, Land Use Regression;

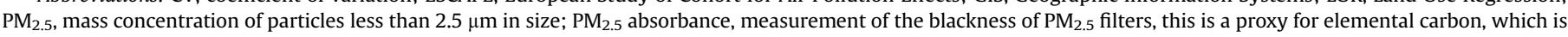

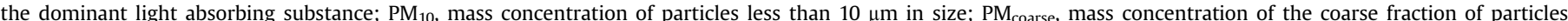

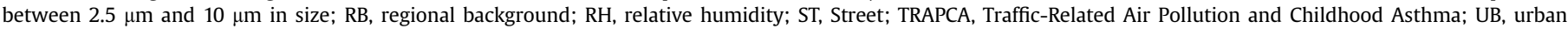
background; US EPA, United States Environmental Protection Agency.

* Corresponding author. Tel.: +313025394 96; fax: +31302539499.

E-mail addresses: M.R.Eeftens@uu.nl (M. Eeftens), g.hoek@uu.nl (G. Hoek).
} 
H I G H L I G H T S

- We used one method to measure $\mathrm{PM}_{2.5}, \mathrm{PM}_{2.5}$ absorbance \& $\mathrm{PM}_{10}$ in 20 European areas.

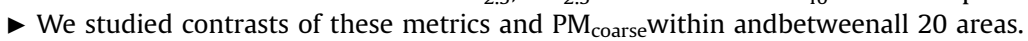

- Concentrationswerehigher in Southern than in Western and Northern European areas.

- Within-area contrasts varied by area andwerelarger for $\mathrm{PM}_{2.5}$ absorbance \& $\mathrm{PM}_{\text {coarse }}$.

- Concentration ratios of particle metrics and $\mathrm{NO}_{2}$ varied significantly across areas.

\section{A $R$ R T I C L E I N F O}

\section{Article history:}

Received 1 February 2012

Received in revised form

13 August 2012

Accepted 15 August 2012

\section{Keywords:}

Traffic

$\mathrm{PM}_{2.5}$

$\mathrm{PM}_{10}$

Coarse particle

Soot

Spatial variation

\begin{abstract}
A B S T R A C T
The ESCAPE study (European Study of Cohorts for Air Pollution Effects) investigates relationships between long-term exposure to outdoor air pollution and health using cohort studies across Europe. This paper analyses the spatial variation of $\mathrm{PM}_{2.5}, \mathrm{PM}_{2.5}$ absorbance, $\mathrm{PM}_{10}$ and $\mathrm{PM}_{\text {coarse concentrations }}$ between and within 20 study areas across Europe.

We measured $\mathrm{NO}_{2}, \mathrm{NO}_{x}, \mathrm{PM}_{2.5}, \mathrm{PM}_{2.5}$ absorbance and $\mathrm{PM}_{10}$ between October 2008 and April 2011 using standardized methods. $\mathrm{PM}_{\text {coarse }}$ was determined as the difference between $\mathrm{PM}_{10}$ and $\mathrm{PM}_{2.5}$. In each of the twenty study areas, we selected twenty PM monitoring sites to represent the variability in important air quality predictors, including population density, traffic intensity and altitude. Each site was monitored over three 14-day periods spread over a year, using Harvard impactors. Results for each site were averaged after correcting for temporal variation using data obtained from a reference site, which was operated year-round.

Substantial concentration differences were observed between and within study areas. Concentrations for all components were higher in Southern Europe than in Western and Northern Europe, but the pattern differed per component with the highest average $\mathrm{PM}_{2.5}$ concentrations found in Turin and the highest $\mathrm{PM}_{\text {coarse }}$ in Heraklion. Street/urban background concentration ratios for $\mathrm{PM}_{\text {coarse }}$ (mean ratio 1.42) were as large as for $\mathrm{PM}_{2.5}$ absorbance (mean ratio 1.38) and higher than those for $\mathrm{PM}_{2.5}(1.14)$ and $\mathrm{PM}_{10}$ (1.23), documenting the importance of non-tailpipe emissions. Correlations between components varied between areas, but were generally high between $\mathrm{NO}_{2}$ and $\mathrm{PM}_{2.5}$ absorbance (average $R^{2}=0.80$ ). Correlations between $\mathrm{PM}_{2.5}$ and $\mathrm{PM}_{\text {coarse }}$ were lower (average $R^{2}=0.39$ ). Despite high correlations, concentration ratios between components varied, e.g. the $\mathrm{NO}_{2} / \mathrm{PM}_{2.5}$ ratio varied between 0.67 and 3.06 .

In conclusion, substantial variability was found in spatial patterns of $\mathrm{PM}_{2.5}, \mathrm{PM}_{2.5}$ absorbance, $\mathrm{PM}_{10}$

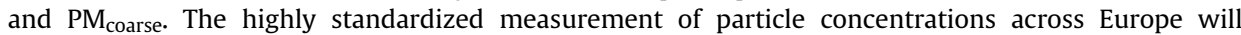
contribute to a consistent assessment of health effects across Europe.
\end{abstract}

(c) 2012 Elsevier Ltd. All rights reserved.

\section{Introduction}

Human exposure to ambient levels of air pollution is a risk to public health (Brunekreef and Holgate, 2002; Pope and Dockery, 2006; WHO, 2006). It has been estimated that, in Europe, exposure to outdoor and traffic-related air pollution has greater adverse effects on public health in the long term, versus the short term (Künzli et al., 2000). Epidemiological studies have suggested associations of long-term exposure to current air pollution levels and particularly cardio-respiratory health (Brunekreef and Holgate, 2002; Rückerl et al., 2011). Most studies have found associations of health with particulate matter characterized as the mass concentration of particles smaller than 2.5 or $10 \mu \mathrm{m}\left(\mathrm{PM}_{2.5}\right.$ or $\left.\mathrm{PM}_{10}\right)$ and nitrogen dioxide $\left(\mathrm{NO}_{2}\right)$ (Brunekreef and Holgate, 2002). In the EU, the air quality limit values for $\mathrm{PM}_{10}$ and $\mathrm{NO}_{2}$ are still exceeded frequently (European Environment Agency (EEA) 2009; Velders and Diederen 2009), raising significant public concern. Less information is available concerning the exceedance of the new $\mathrm{PM}_{2.5}$ guideline (Brunekreef and Maynard, 2008).

Early epidemiological studies compared air pollution concentrations and health outcomes between cities, and have mostly ignored within city variability. Long-term city pollution levels were often characterized by a single (averaged) concentration, based on a limited number of monitors per city, e.g. the American Six Cities Study (Dockery et al., 1993) the American Cancer Society (ACS) study (Pope et al., 2002) and the ECRHS study in Europe (Götschi et al., 2005). Multiple recent studies have shown significant intraurban spatial contrasts (Beelen et al., 2007; Hoek et al., 2002a;
Jerrett et al., 2005b). Land Use Regression (LUR) modelling has been used frequently to explain these spatial contrasts, using predictor variables derived from Geographic Information Systems (GIS) (Hoek et al., 2008; Jerrett et al., 2005a). Several epidemiological studies have since made use of estimated within-urban pollution contrasts based on LUR models (e.g. Morgenstern et al., 2007; Beelen et al., 2008) often focussing mainly on motorized traffic as an important source of intra-urban air pollution contrast (HEI, 2010).

Significant variability of $\mathrm{PM}_{10}$ concentrations between cities across Europe has been reported based upon routine monitoring data (European Environment Agency (EEA) 2009), a series of research projects (Putaud et al., 2004; Van Dingenen et al., 2004) and a wintertime study in 14 European cities (Hoek et al., 1997). The lowest concentrations were generally found in Northern Europe and the highest in Southern and Eastern Europe. Spatial variation of $\mathrm{PM}_{2.5}$ across Europe is less well characterized because it is not routinely measured in most monitoring networks. Nevertheless, significant north-south gradients have been reported for $\mathrm{PM}_{2.5}$ based on research projects (Van Dingenen et al., 2004) and a purpose designed network consisting of 21 urban background stations across Europe (Götschi et al., 2005; Hazenkamp-von Arx et al., 2004). Within-urban contrasts have been characterized in various studies (Monn, 2001; Hoek et al., 2002b), but there are few. The interpretation of spatial contrasts of PM concentrations is limited by differences in site selection, and differences of sampling and analysis methods including different correction factors used to compensate for sampling losses of volatile components between 
countries and network operators (European Environment Agency (EEA) 2009; Van Dingenen et al., 2004). Furthermore, there is limited information on the spatial patterns of the coarse fraction, except from a few research projects (Van Dingenen et al., 2004; Puustinen et al., 2007). Yet, there is increasing epidemiological evidence of the adverse health effects of coarse particles (Brunekreef and Forsberg, 2005).

Ambient concentrations of $\mathrm{PM}_{2.5}, \mathrm{PM}_{10}$, particle composition, $\mathrm{NO}_{2}$ and $\mathrm{NO}_{x}$ were measured in the framework of the ESCAPE project (European Study of Cohorts for Air Pollution Effects; www. escapeproject.eu). The objective of ESCAPE is to investigate the health effects of long-term exposure to ambient air pollution in 36 study areas across Europe. Individual exposure estimates for cohort subjects will be assigned based on predictions of land-use regression (LUR) models (Hoek et al., 2008), which are developed based on the air pollution measurements and geographic predictors. The study areas were selected because of the availability of informative cohort studies in these areas. We decided on performing studyspecific sampling as most existing monitoring networks have insufficient density to capture small-scale spatial variation; locations may not be representative for human, residential exposures, or do not measure all components of interest routinely (e.g. $\mathrm{PM}_{2.5}$, $\mathrm{PM}_{2.5}$ absorbance). While $\mathrm{NO}_{2}$ and $\mathrm{NO}_{x}$ were measured in all 36 areas, particulate matter was measured in 20 out of 36 areas. In each of the 20 areas, PM measurements were made at 20 sites using a standardized protocol using identical gravimetric samplers.

The aim of this paper is to assess the spatial contrasts of $\mathrm{PM}_{2.5}$, $\mathrm{PM}_{2.5}$ absorbance, $\mathrm{PM}_{10}$, and $\mathrm{PM}_{\text {coarse }}$ within and between areas. $\mathrm{A}$ second aim is to assess the variability of differences between regional background, urban background and street locations across Europe, as a likely source of within-area variability. The third aim is to assess the variability in concentrations ratios and correlations between the various particle metrics and $\mathrm{NO}_{2}$ across Europe. A detailed analysis of the spatial contrast for $\mathrm{NO}_{2}$ and $\mathrm{NO}_{x}$ will be reported separately (Cyrys et al., 2012).

\section{Methods}

\subsection{Sampling design}

Particulate matter was measured in 20 study areas (Fig. 1). In each study area, 20 sites were measured. Sampling campaigns were conducted over an entire year, Measurements took place in all study areas between October 2008 and April 2011. Participating centres used identical sampling protocols and common criteria for the selection of sampling sites. Furthermore, they employed the same equipment and all samples were analysed centrally at one laboratory (IRAS, Utrecht University). Calculation of the concentrations was performed using identical templates, which were extensively checked by the coordinating institute.

\subsection{Sampling site selection}

Most study areas included a major city and its surroundings, while others comprised several cities or larger areas. In 18 study areas, 20 sampling sites were selected. In the large study areas of Catalunya and The Netherlands/Belgium, two neighbouring areas were combined and treated as one study area to comprise a total of 40 monitoring sites. In Catalunya, 20 sites were located in the city of Barcelona. Separate LUR models were made for Barcelona and Catalunya. Therefore, Barcelona and Catalunya areas are presented separately throughout this paper. An overview of the study area characteristics can be found in Table 1, and more detailed descriptions and maps of the individual study areas in Online Supplement A.
All participating centres selected sampling sites locally, by considering the spatial distribution of the cohorts of interest and the specific characteristics of the study area. Measurement sites were selected to reflect a large diversity of potential sources of air pollution variability (e.g. population density, traffic intensity, industry, proximity to harbours etc). In each area, we selected regional background, urban background and street sites. Regional background sites were located outside of major urban areas, and were not influenced directly by traffic sources. Urban background sites were located inside an urban area, but at least $50 \mathrm{~m}$ away from major roads. Street sites were selected at building facades representative for homes, in streets with traffic intensities of around 10,000 vehicles per day or more. All sites were selected so that the influence of other local sources of particulate matter and combustion gases (e.g. construction works, district heating plants, parking lots) within $100 \mathrm{~m}$ was minimized. Because of the importance of motorized traffic, we chose to over-represent street sites. We included a variety of streets with different traffic intensity, distance of the sampling site to the road, and different street configurations. Site selection proposals were evaluated centrally, to ensure that all centres applied the same selection criteria.

To adjust for the temporal variability of concentrations, one centrally located reference site was chosen in each study area where measurements were taken over an entire year, following the design of a previous study (Hoek et al., 2002b) and other LUR studies (Hoek et al., 2008). The reference site was chosen at a regional or urban background location, not directly influenced by local sources.

\subsection{Sampling schedule}

For each site, PM measurements were done 3 times for 14 days, in different seasons. Due to a limited amount of samplers, five sites and the reference site were measured simultaneously representing all different site types (regional background, urban background and street). Due to a limited amount of samplers, it was not feasible to measure at all sites simultaneously within a study area. The 14-day average measurements at the reference site continued between and after measurement rounds for a full year. If a measurement at one of the sites failed, it was repeated in a later round for all components, to ensure that three valid measurements were available for each site.

\subsection{Measurement methods}

The standard operating procedure is available from the ESCAPE project website (http://www.escapeproject.eu/manuals/). All particulate matter samples were collected using Harvard impactors, designed to collect particles smaller than $2.5 \mu \mathrm{m}\left(\mathrm{PM}_{2.5}\right)$ or smaller than $10 \mu \mathrm{m}\left(\mathrm{PM}_{10}\right)$ at a flow rate of $101 \mathrm{~min}^{-1}$ (Hoek et al., 2002b; Brunekreef et al., 2005). The air flow was measured before and after sampling, using the same type of rotameters. Rotameters were centrally provided and calibrated at Utrecht University before and after the sampling year, using a soap film device. Samples with a start or end flow below $8.01 \mathrm{~min}^{-1}$ were excluded. Total sampling volume was calculated for each filter based on the average flow and total sampling time. A single pump unit was used at each site, operating both the $\mathrm{PM}_{2.5}$ and $\mathrm{PM}_{10}$ inlets simultaneously. To prevent overload of filters, we employed timers which were set to sample for 15 min every $2 \mathrm{~h}$ (12:00-12:15, 2:00-2:15, 4:00-4:15 etc) so that effectively a 42-h sample was collected over 14 days. Total runtime was recorded by elapsed time counters. Samples which had a sampling duration of less than 28 or more than $56 \mathrm{~h}$ $( \pm 33 \%$ of $42 \mathrm{~h})$ were excluded from analysis. Failed measurements were repeated in a later round for all components. 


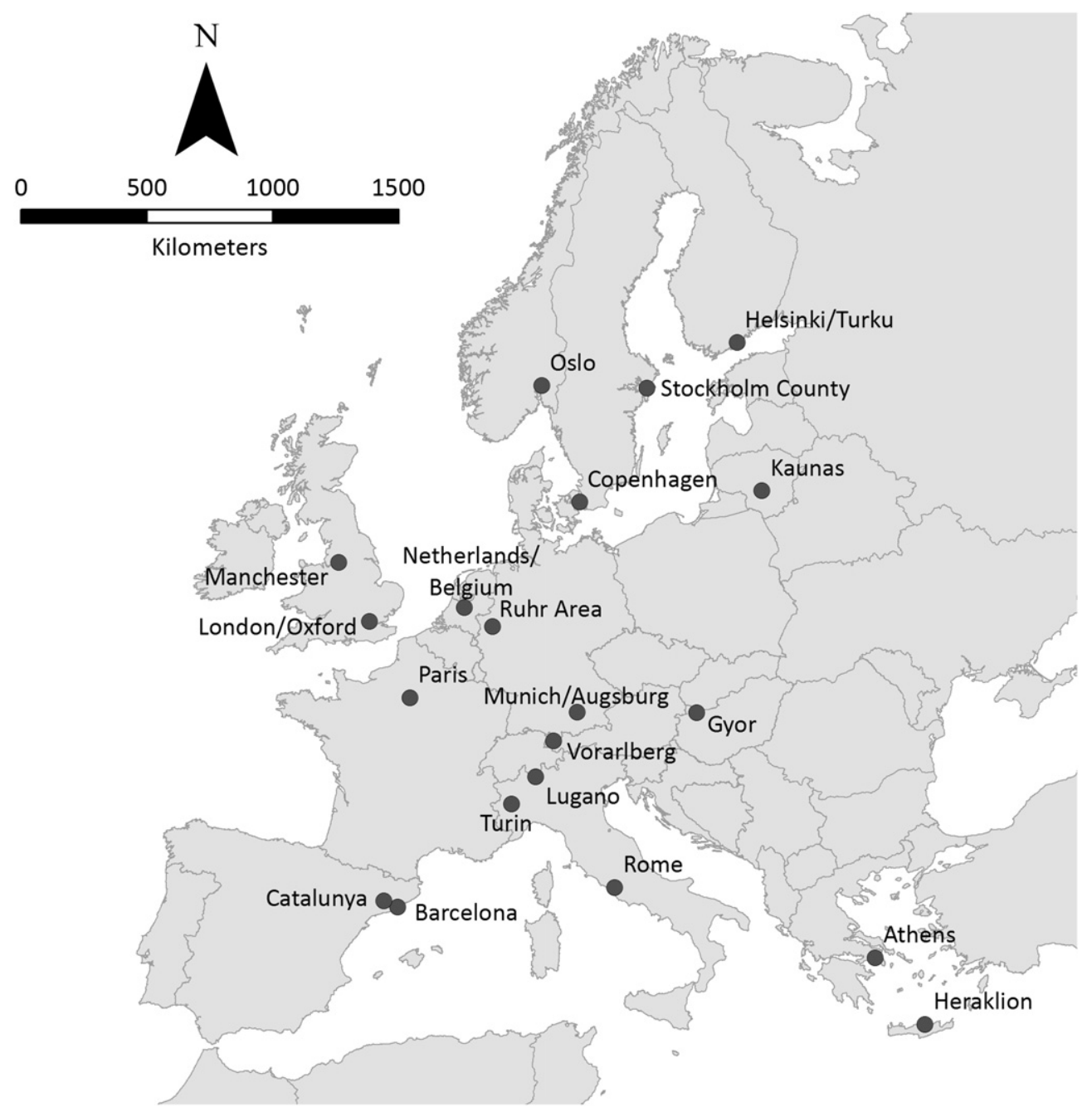

Fig. 1. The ESCAPE study areas.

Table 1

Descriptive characteristics of 20 ESCAPE study areas where airborne particulate matter was measured.

\begin{tabular}{|c|c|c|c|c|c|c|}
\hline Country & Study area & Study area description; major cities & Year & Dates & $\begin{array}{l}\text { Total } \\
\text { number } \\
\text { of sites }\end{array}$ & $\begin{array}{l}\text { Distribution } \\
\text { over site types: } \\
\text { (RB/UB/ST) }\end{array}$ \\
\hline Norway & Oslo & Oslo city & 1 & $05-02-2009-29-01-2010$ & $19^{\mathrm{a}}$ & $3 / 9 / 8$ \\
\hline Sweden & Stockholm County & Stockholm County; Stockholm & 1 & 03-12-2008-01-12-2009 & 20 & $3 / 6 / 11$ \\
\hline Finland & Helsinki/Turku & Two areas: Helsinki/Vantaa and Turku/Loimaa & 2 & $27-01-2010-26-01-2011$ & 20 & $2 / 10 / 8$ \\
\hline Denmark & Copenhagen & Copenhagen city and Hillerød & 2 & $19-11-2009-17-11-2010$ & 20 & $3 / 6 / 11$ \\
\hline Lithuania & Kaunas & Kaunas city & 2 & $20-01-2010-19-01-2011$ & 20 & $4 / 6 / 10$ \\
\hline \multirow[t]{2}{*}{ United Kingdom } & Manchester & Greater Manchester urban area & 1 & $27-01-2009-20-01-2010$ & 20 & $0 / 8 / 12$ \\
\hline & London/Oxford & Thames valley: London, Oxford and smaller towns & 2 & $26-01-2010-18-01-2011$ & 20 & $1 / 12 / 7$ \\
\hline $\begin{array}{l}\text { Netherlands/ } \\
\text { Belgium }\end{array}$ & Netherlands/Belgium & $\begin{array}{l}\text { Entire Country: Amsterdam, Rotterdam, Antwerp, } \\
\text { Utrecht, Groningen, Maastricht, Doetinchem, } \\
\text { Amersfoort and smaller towns }\end{array}$ & 1 & $17-02-2009-19-02-2010$ & 40 & $10 / 12 / 18$ \\
\hline \multirow[t]{2}{*}{ Germany } & Ruhr area & Dortmund, Duisburg, Essen and smaller towns & 1 & $15-10-2008-12-10-2009$ & 20 & $4 / 8 / 8$ \\
\hline & Munich/Augsburg & Munich, Augsburg and smaller surrounding towns & 1 & $27-10-2008-05-11-2009$ & 20 & $5 / 6 / 9$ \\
\hline Austria & Vorarlberg & Cities and areas along the main valley of Vorarlberg & 2 & $03-03-2010-16-02-2011$ & 20 & $3 / 7 / 10$ \\
\hline France & Paris & Paris city and suburban areas & 2 & $04-01-2010-04-01-2011$ & 20 & $4 / 9 / 7$ \\
\hline Hungary & Gyor & Gyor city and neighbouring villages & 2 & $22-02-2010-24-02-2011$ & 20 & $1 / 9 / 10$ \\
\hline Switzerland & Lugano & Lugano city and its neighbouring communities & 1 & $02-03-2009-10-03-2010$ & $18^{\mathrm{a}}$ & $3 / 6 / 10$ \\
\hline \multirow[t]{2}{*}{ Italy } & Turin & $\begin{array}{l}\text { Turin city and five smaller municipalities (Collegno, } \\
\text { Moncalieri, Grugliasco, Nichelino, Rivoli) }\end{array}$ & 2 & 01-02-2010-25-01-2011 & 20 & $1 / 8 / 11$ \\
\hline & Rome & Rome city & 2 & $27-01-2010-26-01-2011$ & 20 & $2 / 8 / 10$ \\
\hline \multirow[t]{2}{*}{ Spain } & Barcelona & Barcelona city & 1 & $14-01-2009-14-01-2010$ & 20 & $1 / 8 / 11$ \\
\hline & Catalunya & Three areas around Barcelona, Girona, Sabadell & 1 & $14-01-2009-14-01-2010$ & 40 & $4 / 13 / 23$ \\
\hline \multirow[t]{2}{*}{ Greece } & Athens & Greater Athens area, 16 municipalities; Athens & 2 & $21-04-2010-27-04-2011$ & 20 & $1 / 12 / 7$ \\
\hline & Heraklion & Heraklion prefecture; Heraklion & 1 & $18-02-2009-16-02-2010$ & 20 & $0 / 12 / 8$ \\
\hline
\end{tabular}

Dates refer to the period when the reference site was operated, RB = regional background, UB = urban background and ST $=$ street site.

a Failed measurements explain fewer than 20 sites for Lugano and Oslo. 
The weighing and reflectance protocols are available from the ESCAPE project website (http://www.escapeproject.eu/manuals/). Briefly, we used Andersen $37 \mathrm{~mm} 2 \mu \mathrm{m}$ pore size Teflon filters for particulate matter sampling. All filters were pre- and post-weighed at a central laboratory (IRAS, Utrecht University, Utrecht, The Netherlands) on a microbalance, following a standard operating procedure, previously described in Brunekreef et al. (2005). Prior to each weighing session, filters were conditioned for at least $24 \mathrm{~h}$ inside the weighing room, at a constant temperature of $23 \pm 1{ }^{\circ} \mathrm{C}$ and constant relative humidity of $37 \pm 2 \%$. A Polonium de-ionizer was used to discharge static electricity from the filters prior to weighing. Reflectance of all filters was also measured in the central laboratory after post-weighing, using the same procedure, also described in Brunekreef et al. (2005). Reflectance was transformed into absorbance (a) according to (ISO (International Standardization Organization) 1993) (Equation (1))

$a=\frac{A}{2 V} * \ln \left(\frac{R_{\mathrm{F}}}{R_{\mathrm{S}}}\right)$

Equation (1): Calculation of the absorbance from reflectance measurements. Where $A$ is the area of the stain no the filter $\left(780^{*} 10^{-6} \mathrm{~m}^{2}\right), \mathrm{V}$ is the volume sampled in $\mathrm{m}^{3}, R_{\mathrm{F}}$ is the average reflectance of the field blank filters as percentage of $R_{0}$ (the reflectance of the clean control filter, 100.0 by definition) and $R_{\mathrm{S}}$ is the reflectance of the sample filter as a percentage of $R_{0}$.

Absorbance has previously been found to be highly correlated with elemental carbon (Cyrys et al., 2003). We report only the absorbance of the $\mathrm{PM}_{2.5}$ filters, as most of the elemental carbon is found in the fine fraction (Putaud et al., 2004). Consistently, in the TRAPCA study (Traffic-Related Air Pollution and Childhood Asthma), $\mathrm{PM}_{2.5}$ absorbance was highly correlated with and almost identical to $\mathrm{PM}_{10}$ absorbance (Cyrys et al., 2003). $\mathrm{PM}_{\text {coarse }}$ concentrations were calculated by subtracting $\mathrm{PM}_{2.5}$ from $\mathrm{PM}_{10}$ concentrations.

\subsection{Quality control}

Filters were transported to and from the central laboratory in individual petri dishes, and were sealed and cooled during transport. A field blank and duplicate for $\mathrm{PM}_{10}$ were collected at the reference site during every sampling period. Field blank filters were placed inside unconnected Harvard impactors, and remained on site for 14 days. $\mathrm{PM}_{10}$ field blanks were assumed to be representative of $\mathrm{PM}_{2.5}$ measurements as well, as the same type of filters and impactors were used. The limit of detection was calculated as 3 times the standard deviation of the field blanks. The average field blank concentration was subtracted from each sample to correct for the effects of transport and handling. Reproducibility of the measurements was assessed by calculating the coefficient of variation (CV) from the duplicates and their corresponding samples using Equation (2) (Hoek et al., 2002a,b). Similar to the detection limit, the coefficients of variation calculated for $\mathrm{PM}_{10}$ were assumed to be representative also for $\mathrm{PM}_{2.5}$. Since $\mathrm{PM}_{\text {coarse }}$ is calculated as the difference between $\mathrm{PM}_{10}$ and $\mathrm{PM}_{2.5}$ concentrations, its variance is higher $(\sqrt{2} * S D)$.

$$
C V=\frac{\sqrt{\frac{\sum_{i=1}^{n}\left(S_{i}-D_{i}\right)^{2}}{2 * n}}}{\frac{\sum_{i=1}^{n}\left(S_{i}+D_{i}\right)}{2 * n}} * 100 \%
$$

Equation (2): Calculation of coefficient of variation. Where $n$ is the number of duplicates and $i$ is the sampling round (1 to $n$ ). $\mathrm{S}$ is the concentration of sample $i$ and $D$ is the concentration of corresponding duplicate $i$.

\subsection{Temporal adjustment}

For each round, a temporal correction was calculated as the difference of each individual reference site measurement from the annual mean at the reference site. Subsequently, measurements at all other sites were corrected for temporal variation, by subtracting the correction calculated for that particular round.

Based upon better performance in the TRAPCA study (Hoek et al., 2002b), we used the absolute difference between the yearly average and each individual reference site measurement as a correction instead of the ratio between the two. To verify this assumption, we compared results from the ratio method to those obtained from the difference method in three different areas (Stockholm County, the Netherlands/Belgium and Catalunya) and report the results in Online supplement B.

\subsection{Data analysis}

Locally calculated adjusted annual averages were gathered centrally and their range and distribution were calculated, stratified by site type. To quantify the amount of spatial variation, the total range (maximum-minimum) was calculated as a percentage of the mean. For each study area, we used ANOVA (SAS 9.2, PROC GLM) to test for significant differences between urban background and street sites and (where applicable) between urban and regional background sites. We also tested if urban background levels differed significantly between study areas. The same analyses were performed for street sites and regional background sites (where applicable), again using SAS 9.2, PROC GLM. Relationships between concentrations of pollutants were expressed as $R^{2}$-values determined using SAS 9.2, PROC REG. $R^{2}$ is the Pearson correlation squared. Percentages of between and within area variance were determined using analysis of variance with PROC MIXED. We analysed overall patterns and patterns in three groups of study areas: Northern (Oslo, Stockholm County, Helsinki/Turku, Copenhagen), Southern (Turin, Rome, Barcelona, Catalunya, Athens and Heraklion) and West/Central European (other areas).

\section{Results}

\subsection{Quality control}

Detection limits were low for all centres for both $\mathrm{PM}_{10}(0.7-$ $4.0 \mu \mathrm{g} \mathrm{m}^{-13}$ ) and $\mathrm{PM}_{10}$ absorbance $\left(0.04-0.10 \times 10^{-5} \mathrm{~m}^{-1}\right)$. Only 3 samples ( 2 for $\mathrm{PM}_{2.5}$ and 1 for $\mathrm{PM}_{10}$ ) from Helsinki/Turku were below the detection limit (Online supplement $\mathrm{C}$ ). We retained the original values. Reproducibility was good in most areas, as coefficients of variation (CV) varied between $2 \%$ and $7 \%$ for $\mathrm{PM}_{10}$, and between $2 \%$ and $5 \%$ for $\mathrm{PM}_{10}$ absorbance (Online supplement $\mathrm{C}$ ). $\mathrm{CV}$ values for $\mathrm{PM}_{10}$ in Helsinki/Turku and Manchester were higher (11\% and $37 \%$ respectively), caused in both cases by a single pair of incomparable duplicates.

\subsection{Adjustment for temporal variation}

Unadjusted mean concentrations correlated well with temporally adjusted means for $\mathrm{PM}_{2.5}$ absorbance, $\mathrm{PM}_{10}$ and $\mathrm{PM}_{\text {coarse }}$ for most areas (Online Supplement B, Table B.1). For $\mathrm{PM}_{2.5}$, adjusted mean concentrations correlated moderately with unadjusted means. The more moderate correlations for $\mathrm{PM}_{2.5}$ are probably due to relatively large temporal variation compared to other components (Online Supplement B, Table B.2). A comparison between the 
difference and ratio adjustment approaches in Catalunya, Stockholm and the Netherlands revealed that adjusted concentrations from both methods were highly correlated with each other for all three selected areas (Online Supplement B, Table B.3).

\subsection{Spatial variability within and between study areas}

Spatial variability of the average concentration for all components between and within study areas is shown in Fig. 2A-D and Table 2 , respectively. Contrasts between background and street sites are shown in Figs. 3-6.

\subsection{1. $P M_{2.5}$}

Concentration levels of $\mathrm{PM}_{2.5}$ were lowest in the Northern European study areas and highest in the Southern European (particularly Turin) and two Eastern European study areas (Gyor and Kaunas). Clear regional patterns are visible, e.g. with similar concentrations in the Netherlands/Belgium and the Ruhr Area, which exceed those measured in London and Manchester (Fig. 2A). There was substantial variation within most study areas. The lowest contrasts (range $<50 \%$ of the mean) were found in Manchester, Ruhr area, Gyor, and Turin (Table 2). Absolute $\mathrm{PM}_{2.5}$ contrasts were largest in the Southern study areas: Rome, Barcelona and Catalunya (Fig. 3).

Concentrations at street sites were significantly higher than those at urban background sites for 12 out of the 20 areas (Table 3 ). Street/urban background ratios varied between 0.96 and 1.30, with no differences in ratios between the Northern, Western/central and southern European study areas. Regional/urban background ratios were lower than 1 for all study areas except Munich/Augsburg and Rome (Table 3).

\subsection{2. $P M_{2.5}$ absorbance}

For $\mathrm{PM}_{2.5}$ absorbance, the lowest median concentrations were found in Northern European study areas and Heraklion. The highest concentrations were found in the Southern European study areas (Rome, Turin and Barcelona) (Fig. 2B). Gyor and Kaunas had high concentrations of $\mathrm{PM}_{2.5}$, but only moderately high concentrations of $\mathrm{PM}_{2.5}$ absorbance. In general, within study area contrasts for $\mathrm{PM}_{2.5}$ absorbance were larger than those for $\mathrm{PM}_{2.5}$ (Fig. 4, Table 2).

For all study areas, concentrations were higher at street sites than at urban background sites. Street/urban background ratios varied between 1.02 and 1.77, with statistically significant differences for almost all study areas (Table 3 ). Mean ratios were 1.51 , 1.32 and 1.35 for the Northern, West/Central and Southern
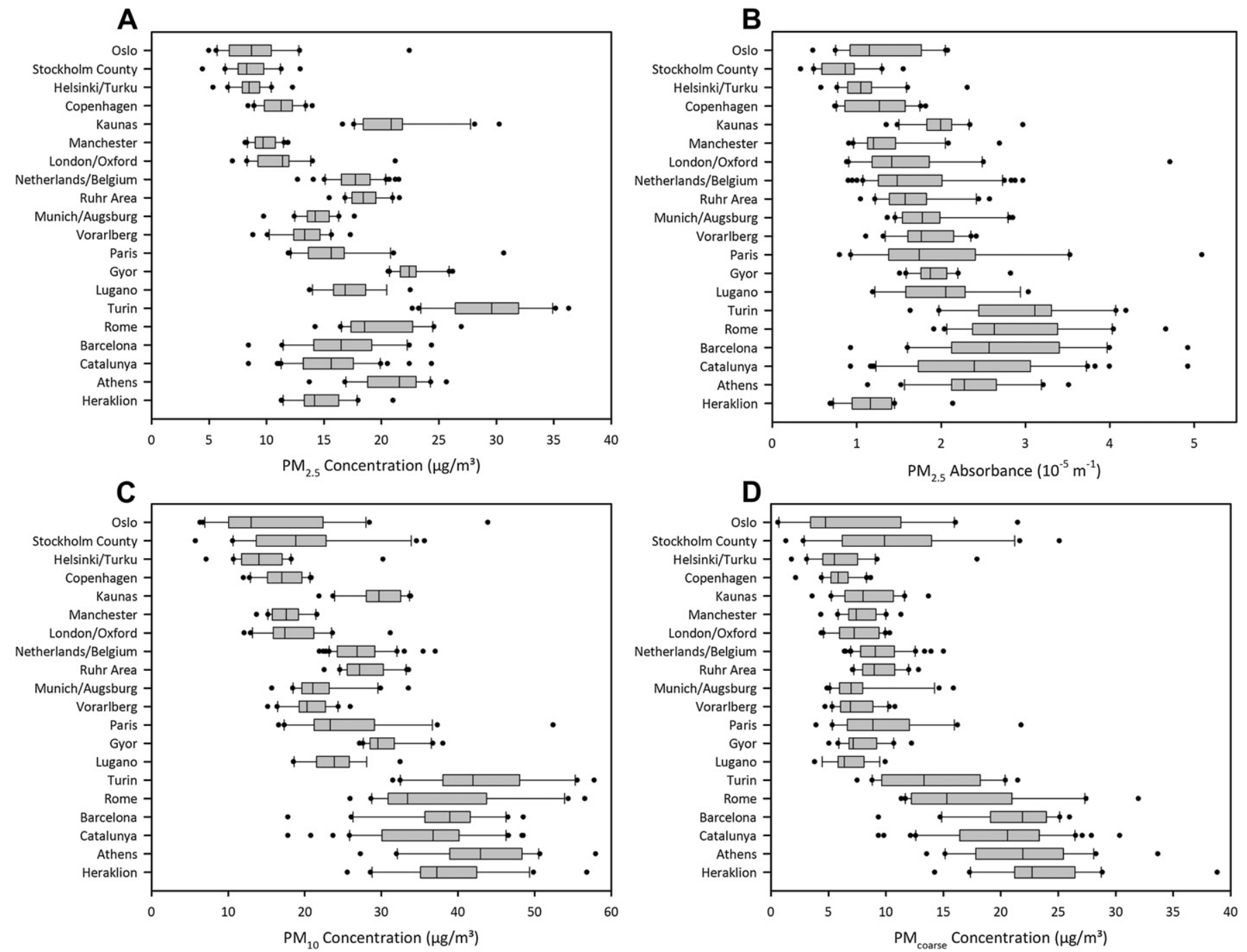

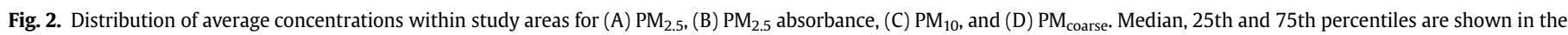
box, whiskers indicate 10th and 90th percentiles and individual outliers are shown as points. 
Table 2

Mean and overall contrasts (total range/mean) of adjusted annual average concentrations of $\mathrm{PM}_{2.5}, \mathrm{PM}_{2.5}$ absorbance, $\mathrm{PM}_{10}$ and $\mathrm{PM}_{\text {coarse }}$ by study area.

\begin{tabular}{|c|c|c|c|c|c|c|c|c|}
\hline \multirow[t]{2}{*}{ Study area } & \multicolumn{2}{|l|}{$\mathrm{PM}_{2.5}$} & \multicolumn{2}{|c|}{$\mathrm{PM}_{2.5}$ absorbance } & \multicolumn{2}{|l|}{$\mathrm{PM}_{10}$} & \multicolumn{2}{|l|}{$\mathrm{PM}_{\text {coarse }}$} \\
\hline & Mean $(n)$ & Range/mean (\%) & Mean $(n)$ & Range/mean (\%) & Mean $(n)$ & Range/mean (\%) & Mean $(n)$ & Range/mean (\%) \\
\hline Oslo & $8.6(20)$ & $91 \%$ & $1.3(20)$ & $109 \%$ & $14.8(19)$ & $149 \%$ & $6.1(19)$ & $259 \%$ \\
\hline Stockholm County & $8.5(20)$ & $100 \%$ & $0.8(20)$ & $144 \%$ & $19.1(20)$ & $156 \%$ & $10.6(20)$ & $224 \%$ \\
\hline Helsinki/Turku & $8.6(20)$ & $80 \%$ & $1.1(20)$ & $155 \%$ & $14.8(20)$ & $156 \%$ & $6.2(20)$ & $260 \%$ \\
\hline Copenhagen & $11.1(20)$ & $50 \%$ & $1.2(20)$ & $88 \%$ & $17.1(20)$ & $52 \%$ & $6.0(20)$ & $109 \%$ \\
\hline Kaunas & $21.1(20)$ & $65 \%$ & $2.0(20)$ & $81 \%$ & $29.5(20)$ & $41 \%$ & $8.4(20)$ & $121 \%$ \\
\hline Manchester & $9.8(20)$ & $38 \%$ & $1.4(20)$ & $132 \%$ & $17.6(20)$ & $45 \%$ & $7.7(20)$ & $90 \%$ \\
\hline London/Oxford & $11.2(20)$ & $127 \%$ & $1.6(20)$ & $235 \%$ & $18.6(20)$ & $103 \%$ & $7.4(20)$ & $81 \%$ \\
\hline Netherlands/Belgium & $17.7(40)$ & $50 \%$ & $1.7(40)$ & $123 \%$ & $27.1(40)$ & $56 \%$ & $9.3(40)$ & $92 \%$ \\
\hline Ruhr Area & $18.5(20)$ & $33 \%$ & $1.6(20)$ & $93 \%$ & $27.9(20)$ & $39 \%$ & $9.4(20)$ & $61 \%$ \\
\hline Munich/Augsburg & $14.3(20)$ & $55 \%$ & $1.9(20)$ & $79 \%$ & $22.1(20)$ & $81 \%$ & $7.7(20)$ & $142 \%$ \\
\hline Vorarlberg & $13.3(20)$ & $64 \%$ & $1.8(20)$ & $72 \%$ & $20.6(20)$ & $52 \%$ & $7.3(20)$ & $83 \%$ \\
\hline Paris & $16.0(20)$ & $117 \%$ & $2.0(20)$ & $213 \%$ & $25.6(20)$ & $140 \%$ & $9.6(20)$ & $185 \%$ \\
\hline Gyor & $22.6(20)$ & $25 \%$ & $1.9(20)$ & $68 \%$ & $30.6(20)$ & $36 \%$ & $8.0(20)$ & $90 \%$ \\
\hline Lugano & $17.2(19)$ & $51 \%$ & $2.0(19)$ & $91 \%$ & $23.9(18)$ & $58 \%$ & $6.8(18)$ & $90 \%$ \\
\hline Turin & $29.3(20)$ & $47 \%$ & $3.0(20)$ & $85 \%$ & $43.1(20)$ & $61 \%$ & $13.8(20)$ & $101 \%$ \\
\hline Rome & $19.8(20)$ & $64 \%$ & $2.9(20)$ & $96 \%$ & $37.0(20)$ & $83 \%$ & $17.2(20)$ & $120 \%$ \\
\hline Barcelona & $16.3(20)$ & $97 \%$ & $2.7(20)$ & $146 \%$ & $37.4(20)$ & $82 \%$ & $21.0(20)$ & $79 \%$ \\
\hline Catalunya & $15.6(40)$ & $102 \%$ & $2.5(40)$ & $162 \%$ & $35.6(40)$ & $86 \%$ & $20.0(40)$ & $105 \%$ \\
\hline Athens & $20.9(20)$ & $57 \%$ & $2.4(20)$ & $101 \%$ & $42.8(20)$ & $72 \%$ & $21.9(20)$ & $92 \%$ \\
\hline Heraklion & $14.7(20)$ & $66 \%$ & $1.2(20)$ & $121 \%$ & $38.4(20)$ & $81 \%$ & $23.6(20)$ & $104 \%$ \\
\hline
\end{tabular}

Differences between areas might be affected by different numbers of regional background, urban background and street sites selected.

European areas respectively. Regional background levels were lower than urban background levels for all study areas, with regional/urban ratios varying between 0.45 and 0.92 , with no differences between the Northern, West-Central and Southern European areas (Table 3).

\subsection{3. $P M_{10}$}

The pattern for $\mathrm{PM}_{10}$ was similar to $\mathrm{PM}_{2.5}$ with low concentrations in Northern Europe and high concentrations in southern and Eastern Europe (Fig. 2C). In Heraklion, which had moderate concentrations of $\mathrm{PM}_{2.5}$ and $\mathrm{PM}_{2.5}$ absorbance, high $\mathrm{PM}_{10}$ concentrations were found (Fig. 2C), reflecting coarse particles. Lower contrasts were found in both Kaunas and Gyor study areas (Fig. 5, Table 2).

Street/urban background ratios ranged between 1.03 and 1.76 and were significantly higher than 1 for 13 out of 20 areas (Table 3 ). In nearly all study areas, the street/urban background ratio was higher for $\mathrm{PM}_{10}$ than for $\mathrm{PM}_{2.5}$. In the Northern European study areas the street/urban background ratio (mean 1.43) was higher than in the western (1.15) and southern (1.17). Regional background concentrations were lower than urban background concentrations in all areas (regional/urban ratios between 0.52 and 0.99) (Table 3).

\subsection{4. $P M_{\text {coarse }}$}

Coarse particles exhibited a different spatial pattern than $\mathrm{PM}_{2.5}$. Concentrations were highest in Southern European areas, but the highest concentrations were found in Heraklion, Athens, and Barcelona, with more modest concentrations in Turin and Rome (Fig. 2D). Concentrations in the Northern European areas were low, but did not differ much from the Western and Central European areas (Fig. 2D). In Stockholm County, $\mathrm{PM}_{\text {coarse levels were similar to }}$ those measured in Southern Europe. Contrasts in $\mathrm{PM}_{\text {coarse }}$ were similar to those of $\mathrm{PM}_{10}$, and are similarly high for the Northern European areas (Fig. 6, Table 2).

Street/Urban background ratios were all above 1, ranging from 1.06 to 3.41. This difference was statistically significant in 14 out of 20 study areas (Table 4). Mean street/urban background ratios were 1.97, 1.27 and 1.31 for the Northern, West-Central and Southern European areas respectively. The ratio was typically much larger than for $\mathrm{PM}_{2.5}$ and similar to the ratio observed for absorbance and statistically significant in 14 out of 20 study areas (Table 3). Ratios between regional and urban background levels were only significant in 4 areas, and varied widely between 0.36 and 1.10 (Table 3).

\subsubsection{Analysis of variance}

Between area variance was higher than within area variance for $\mathrm{PM}_{2.5}, \mathrm{PM}_{10}$ and $\mathrm{PM}_{\text {coarse }}(81 \%, 72 \%$ and $71 \%$ of the total, respectively). For $\mathrm{PM}_{\text {coarse }}$ this was mainly caused by the high concentrations in the Southern European study areas (Heraklion, Athens, Barcelona, Catalunya). For $\mathrm{PM}_{2.5}$ absorbance, we found that within area variance (52\% of the total) was slightly larger than between area variance (48\%), indicating that $\mathrm{PM}_{2.5}$ absorbance varies predominantly on a local scale.

\subsection{Relation between the pollutants}

The correlation between the different particle metrics and $\mathrm{NO}_{2}$ within study areas was highly variable across Europe (Table 4). The correlation $\left(R^{2}\right)$ between $\mathrm{PM}_{2.5}$ and $\mathrm{PM}_{10}$ was high: 0.74 (range $0.44-0.95$ ), but the correlation between the fine and coarse fractions $\left(\mathrm{PM}_{2.5}\right.$ and $\left.\mathrm{PM}_{\text {coarse}}\right)$ was moderate 0.39 (range 0.02-0.81). $\mathrm{PM}_{2.5}$ absorbance had a moderately high correlation with the particle mass metrics.

The correlations $\left(R^{2}\right)$ between $\mathrm{NO}_{2}$ and $\mathrm{PM}_{2.5}$ absorbance were generally high: 0.80 (range $0.55-0.91$ ), and were similar between $\mathrm{NO}_{x}$ and $\mathrm{PM}_{2.5}$ absorbance: 0.83 (range $0.41-0.98$ ), while the correlation between $\mathrm{NO}_{2}$ and $\mathrm{PM}_{2.5}$ was much lower: 0.50 (range $0.02-0.90$ ). There was no clear spatial pattern of the correlations across Europe (Table 4).

Despite the high correlation between several components, the ratio of average concentrations varied substantially across study areas (Table 5), thereby indicating the different compositions of these pollution mixtures. The median $\mathrm{NO}_{2} / \mathrm{PM}_{2.5}$ ratio varied from 0.67 to 3.06. The median $\mathrm{PM}_{2.5} / \mathrm{PM}_{2.5}$ absorbance ratio varied between 6.24 and 12.96 . The $\mathrm{PM}_{2.5} / \mathrm{PM}_{10}$ ratio ranged from 0.39 to 0.74 , with the lowest values in the south and higher values in Eastern Europe (Kaunas and Gyor).

\section{Discussion}

We found significant concentration differences for $\mathrm{PM}_{2.5}, \mathrm{PM}_{2.5}$ absorbance, $\mathrm{PM}_{10}$ and $\mathrm{PM}_{\text {coarse }}$ across 20 European study areas. 

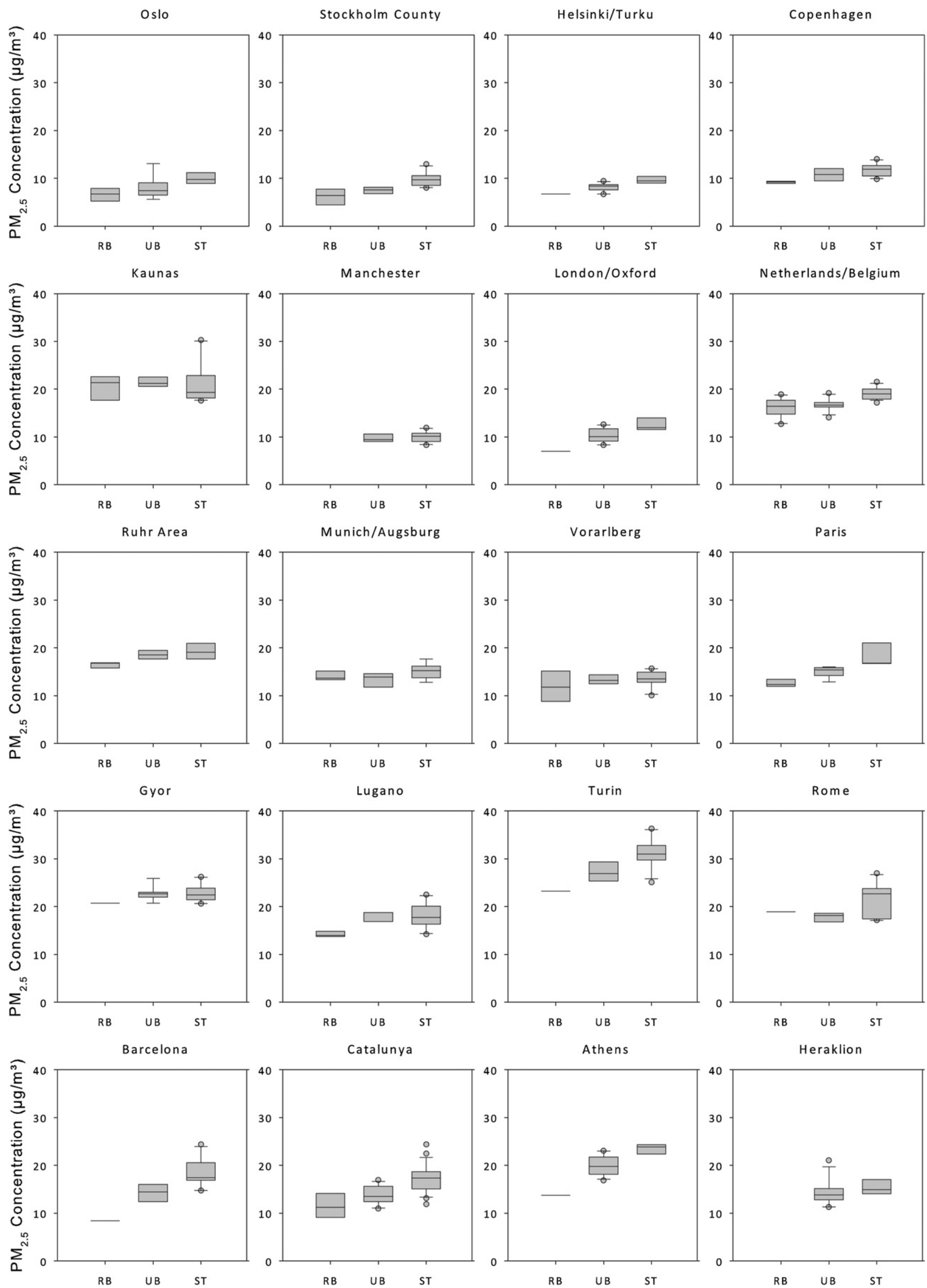

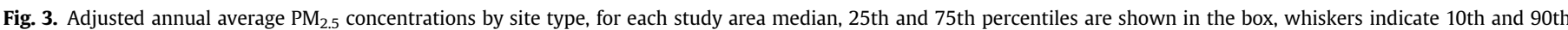
percentiles and individual outliers are shown as points. RB $=$ regional background, UB = urban background and ST $=$ street site. 

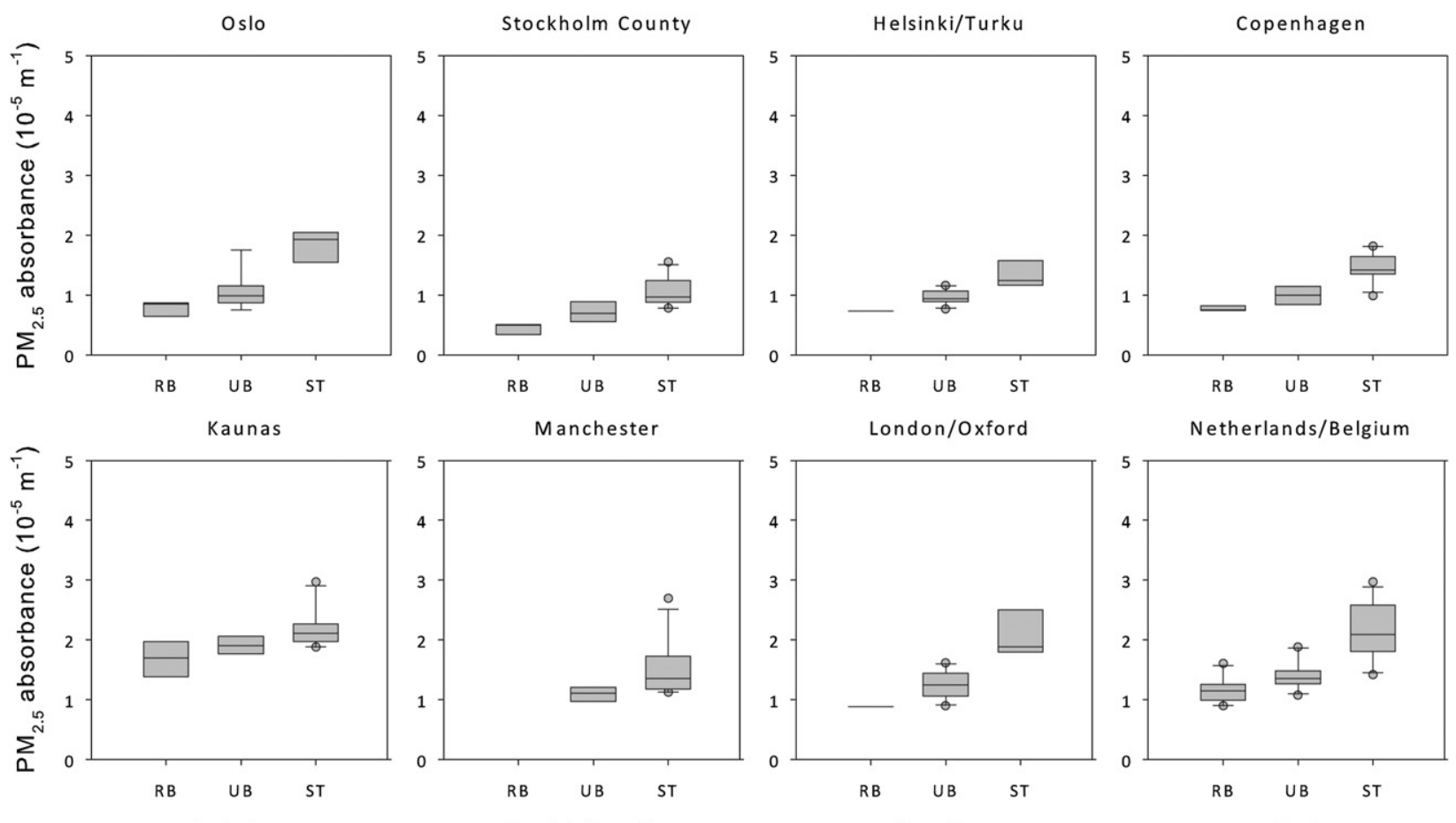

Netherlands/Belgium
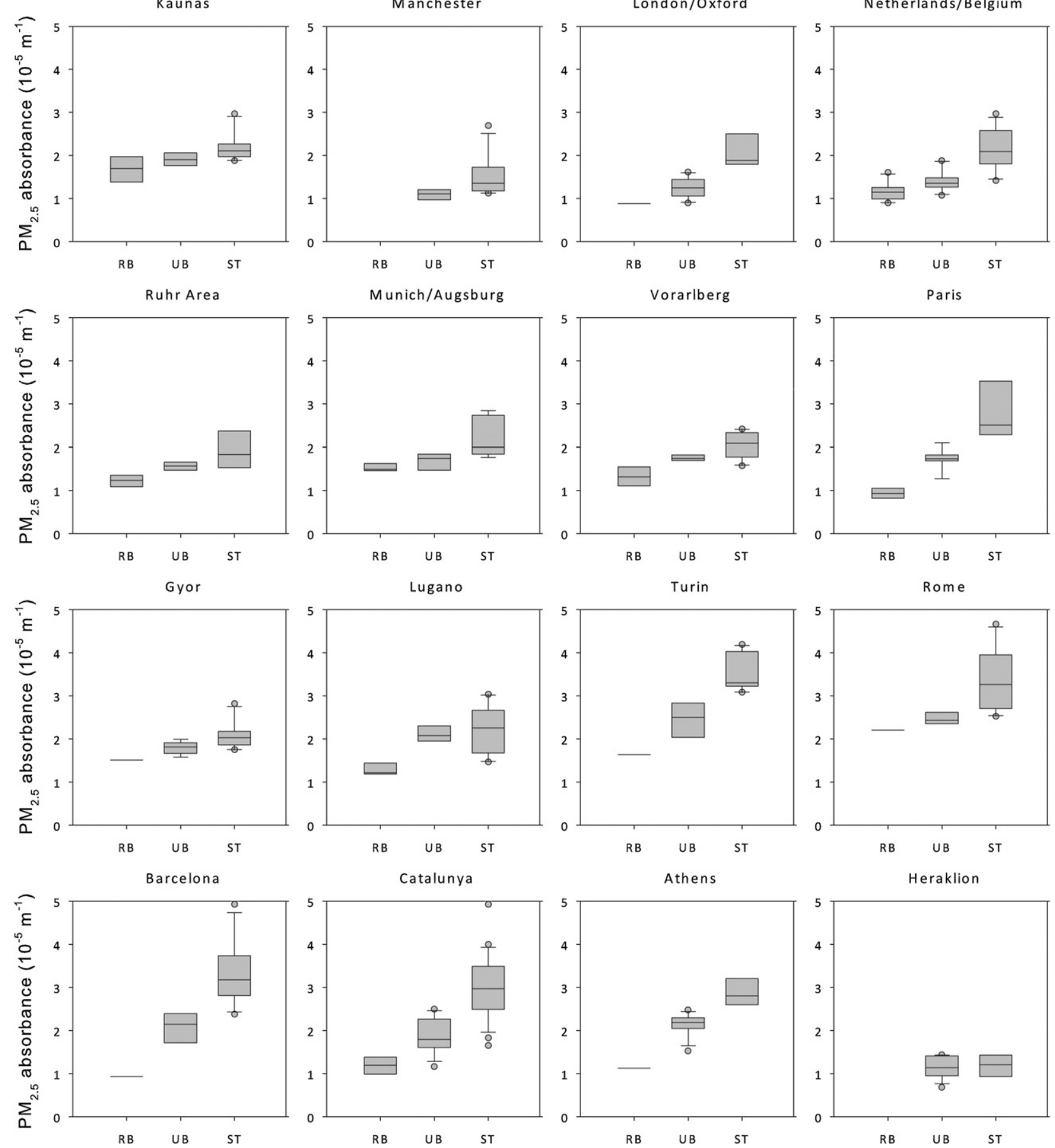

Fig. 4. Adjusted annual average $\mathrm{PM}_{2.5}$ absorbance concentrations by site type, for each study area median, 25 th and 75 th percentiles are shown in the box, whiskers indicate 10 th and 90th percentiles and individual outliers are shown as points. $\mathrm{RB}=$ regional background, $\mathrm{UB}=$ urban background and $\mathrm{ST}=$ street site. 

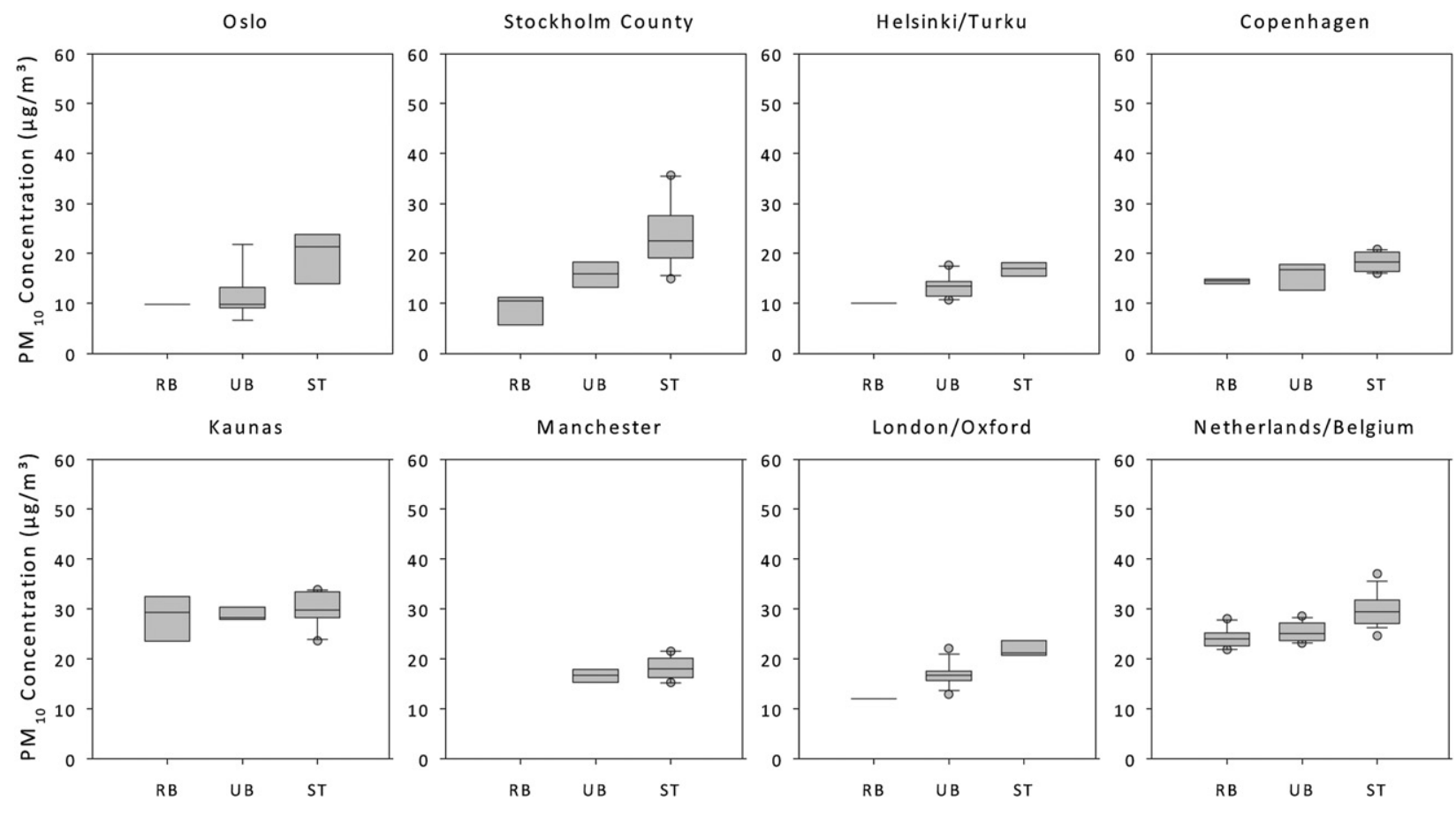

Netherlands/Belgium
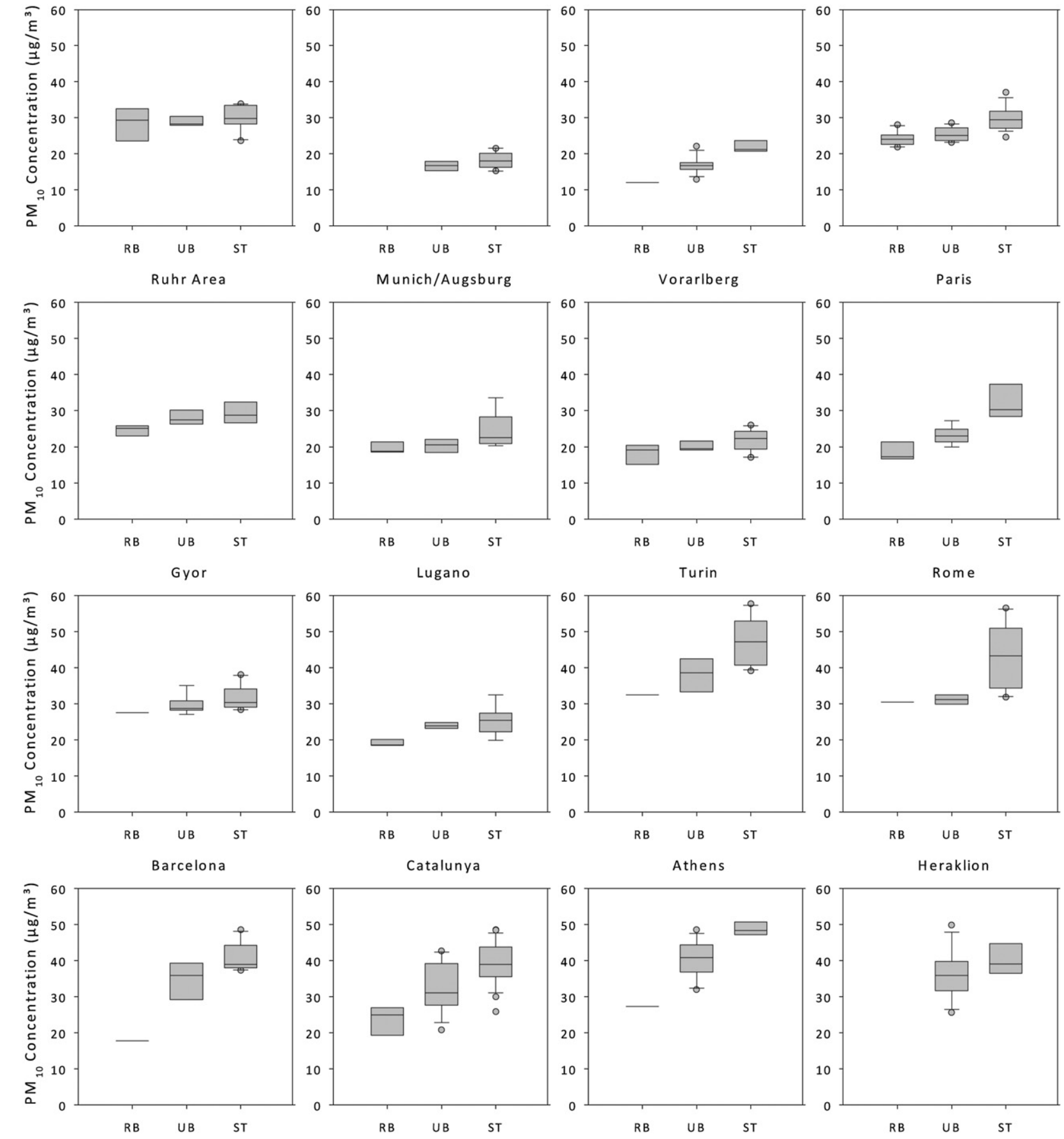

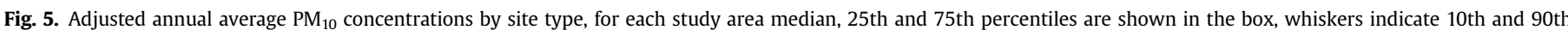
percentiles and individual outliers are shown as points. $\mathrm{RB}=$ regional background, $\mathrm{UB}=$ urban background and ST $=$ street site. 


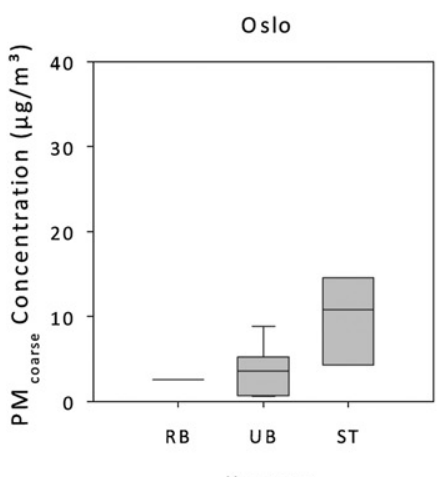

Stockholm County

Helsinki/Turku

Copenhagen
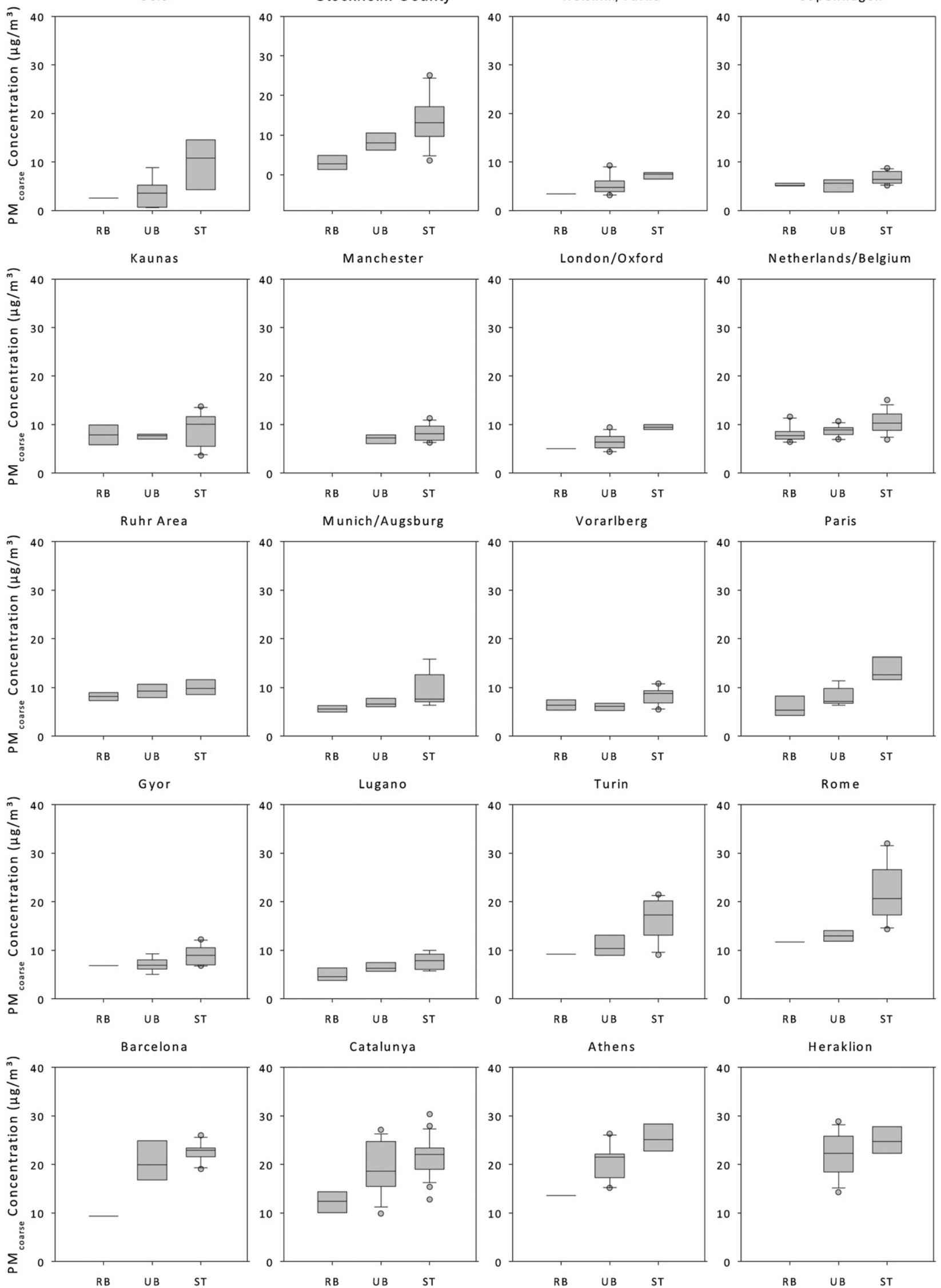

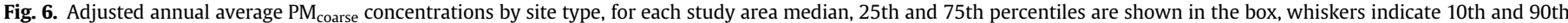
percentiles and individual outliers are shown as points. $\mathrm{RB}=$ regional background, UB $=$ urban background and $\mathrm{ST}=$ street site. 
Table 3

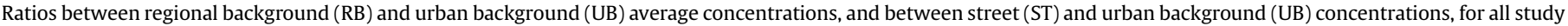
areas

\begin{tabular}{|c|c|c|c|c|c|c|c|c|}
\hline \multirow[t]{2}{*}{ Study_area } & \multicolumn{2}{|l|}{$\mathrm{PM}_{2.5}$} & \multicolumn{2}{|c|}{$\mathrm{PM}_{2.5}$ absorbance } & \multicolumn{2}{|l|}{$\mathrm{PM}_{10}$} & \multicolumn{2}{|c|}{$\mathrm{PM}_{\text {coarse }}$} \\
\hline & $\begin{array}{l}\text { Ratio } \\
\text { RB/UB }\end{array}$ & $\begin{array}{l}\text { Ratio } \\
\text { ST/UB }\end{array}$ & $\begin{array}{l}\text { Ratio } \\
\text { RB/UB }\end{array}$ & $\begin{array}{l}\text { Ratio } \\
\text { ST/UB }\end{array}$ & $\begin{array}{l}\text { Ratio } \\
\text { RB/UB }\end{array}$ & $\begin{array}{l}\text { Ratio } \\
\text { ST/UB }\end{array}$ & $\begin{array}{l}\text { Ratio } \\
\text { RB/UB }\end{array}$ & $\begin{array}{l}\text { Ratio } \\
\text { ST/UB }\end{array}$ \\
\hline Oslo & 0.83 & $1.28^{* *}$ & $0.76^{*}$ & $1.73^{* *}$ & 0.86 & $1.76^{* *}$ & 0.47 & $3.41^{* *}$ \\
\hline Stockholm County & $0.81^{*}$ & $1.29^{* *}$ & $0.62^{* *}$ & $1.42^{* *}$ & $0.56^{* *}$ & $1.45^{* *}$ & $0.32^{* *}$ & $1.53^{*}$ \\
\hline Helsinki/Turku & $0.81^{* *}$ & $1.19^{* *}$ & $0.74^{*}$ & $1.42^{* *}$ & $0.73^{*}$ & $1.33^{* *}$ & 0.61 & $1.56^{* *}$ \\
\hline Copenhagen & $0.86^{*}$ & 1.11 & $0.77^{* *}$ & $1.47^{* *}$ & 0.92 & $1.18^{* *}$ & 1.10 & $1.38^{* *}$ \\
\hline Kaunas & 0.95 & 0.96 & 0.88 & $1.14^{*}$ & 0.97 & 1.03 & 1.03 & 1.13 \\
\hline Manchester & $\mathrm{N} / \mathrm{A}$ & 1.04 & $\mathrm{~N} / \mathrm{A}$ & $1.32^{* *}$ & $\mathrm{~N} / \mathrm{A}$ & $1.11^{*}$ & $\mathrm{~N} / \mathrm{A}$ & $1.20^{*}$ \\
\hline London/Oxford & $0.69 *$ & $1.26^{* *}$ & 0.71 & $1.77^{* *}$ & $0.72^{* *}$ & $1.33^{* *}$ & 0.80 & $1.44^{* * *}$ \\
\hline Netherlands/Belgium & 0.97 & $1.15^{* *}$ & $0.82^{* *}$ & $1.52^{* *}$ & 0.95 & $1.17^{* *}$ & 0.92 & $1.19^{* *}$ \\
\hline Ruhr_Area & $0.88^{* *}$ & 1.03 & $0.77^{* *}$ & $1.19^{*}$ & $0.88^{* *}$ & 1.04 & 0.87 & 1.06 \\
\hline Munich/Augsburg & 1.07 & $1.15^{* *}$ & 0.92 & $1.31^{* *}$ & 0.98 & $1.21^{* *}$ & 0.81 & $1.30^{*}$ \\
\hline Vorarlberg & 0.85 & 0.98 & $0.76^{* *}$ & $1.17^{* *}$ & 0.92 & 1.10 & 1.05 & $1.36^{* * *}$ \\
\hline Paris & $0.83^{*}$ & $1.24^{* *}$ & $0.54^{* *}$ & $1.65^{* *}$ & $0.79^{*}$ & $1.37^{* *}$ & $0.71^{*}$ & $1.61^{* *}$ \\
\hline Gyor & 0.92 & 1.00 & 0.84 & $1.15^{* *}$ & 0.93 & 1.06 & 0.99 & $1.27^{* *}$ \\
\hline Lugano & $0.81^{* *}$ & 1.02 & $0.60^{* *}$ & 1.02 & $0.79^{* *}$ & 1.05 & $0.75^{*}$ & 1.18 \\
\hline Turin & 0.85 & $1.14^{* *}$ & $0.67^{* *}$ & $1.43^{* *}$ & 0.85 & $1.24^{* *}$ & 0.86 & $1.49^{* *}$ \\
\hline Rome & 1.07 & $1.21^{* *}$ & 0.91 & $1.37^{* *}$ & 0.99 & $1.37^{* *}$ & 0.89 & $1.59^{* *}$ \\
\hline Barcelona & $0.60^{* *}$ & $1.30^{* *}$ & $0.45^{* *}$ & $1.59^{* *}$ & $0.52^{* *}$ & $1.19^{* *}$ & $0.46^{* *}$ & 1.11 \\
\hline Catalunya & $0.82^{* *}$ & $1.25^{* *}$ & $0.63^{* *}$ & $1.57^{* *}$ & $0.72^{* *}$ & $1.20^{* *}$ & $0.65^{* *}$ & $1.16^{*}$ \\
\hline Athens & $0.69^{* *}$ & $1.19^{* *}$ & $0.53^{* *}$ & $1.36^{* *}$ & $0.68^{* *}$ & $1.23^{* *}$ & $0.67^{* *}$ & $1.27^{* *}$ \\
\hline Heraklion & $\mathrm{N} / \mathrm{A}$ & 1.09 & $\mathrm{~N} / \mathrm{A}$ & 1.06 & $\mathrm{~N} / \mathrm{A}$ & $1.15^{*}$ & $\mathrm{~N} / \mathrm{A}$ & $1.19^{*}$ \\
\hline Mean & 0.85 & 1.14 & 0.72 & 1.38 & 0.82 & 1.23 & 0.78 & 1.42 \\
\hline
\end{tabular}

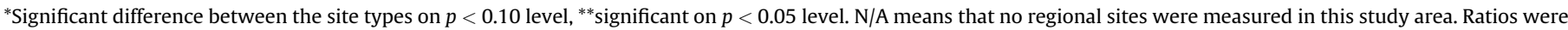
obtained from a regression model with $\log$ (concentrations) as dependent variables and site type as independent variable.

Especially for $\mathrm{PM}_{2.5}$ absorbance and $\mathrm{PM}_{\text {coarse }}$ we saw significant contrasts within study areas. For $\mathrm{PM}_{2.5}$ absorbance, the contrast within study areas was larger than between study areas. Concentrations at street sites were higher than at urban background sites for all components, but the ratios differed widely across the study areas. $\mathrm{PM}_{10}$ and $\mathrm{PM}_{2.5}$ concentrations generally correlated well with $\mathrm{NO}_{2}$ and absorbance, however, the ratios of absolute concentrations differed substantially.

The strength of this study is that we used a standardized approach for selecting sampling sites, a common study setup, the same equipment, identical sampling protocols and that all analyses were done by one central laboratory, so spatial contrasts could be compared both within and between the 20 study areas. This allowed us to assess the true variability across Europe of concentrations of fine and coarse particulate matter; the relation of various PM metrics (correlation and ratio); the variability of the increment at street sites relative to urban background. Our results indicate significant differences in the PM mixture across Europe which are not due to differences in measurement methods We used a gravimetric method to measure $\mathrm{PM}_{10}$ which is less affected by losses of

Table 4

Correlation $\left(R^{2}\right)$ between annual average concentrations for different components.

\begin{tabular}{|c|c|c|c|c|c|c|c|c|c|c|}
\hline \multirow[t]{2}{*}{ Study_area } & \multicolumn{4}{|l|}{$\mathrm{NO}_{2}$} & \multicolumn{3}{|l|}{$\mathrm{PM}_{2.5}$} & \multicolumn{2}{|c|}{$\mathrm{PM}_{2.5}$ absorbance } & \multirow{2}{*}{$\frac{\mathrm{PM}_{10}}{\mathrm{PM}_{\text {coarse }}}$} \\
\hline & $\mathrm{PM}_{2.5}$ & $\begin{array}{l}\mathrm{PM}_{2.5} \\
\text { absorbance }\end{array}$ & $\mathrm{PM}_{10}$ & $\mathrm{PM}_{\text {coarse }}$ & $\begin{array}{l}\mathrm{PM}_{2.5} \\
\text { absorbance }\end{array}$ & $\mathrm{PM}_{10}$ & $\mathrm{PM}_{\text {coarse }}$ & $\mathrm{PM}_{10}$ & $\mathrm{PM}_{\text {coarse }}$ & \\
\hline Oslo & 0.24 & 0.74 & 0.34 & 0.29 & 0.61 & 0.62 & 0.37 & 0.48 & 0.34 & 0.93 \\
\hline Stockholm County & 0.75 & 0.88 & 0.80 & 0.68 & 0.78 & 0.62 & 0.42 & 0.85 & 0.73 & 0.96 \\
\hline HelsinkiTurku & 0.71 & 0.81 & 0.80 & 0.75 & 0.80 & 0.84 & 0.69 & 0.81 & 0.74 & 0.97 \\
\hline Copenhagen & 0.40 & 0.86 & 0.60 & 0.50 & 0.44 & 0.75 & 0.22 & 0.54 & 0.36 & 0.71 \\
\hline Kaunas & 0.04 & 0.55 & 0.17 & 0.06 & 0.23 & 0.50 & 0.20 & 0.30 & 0.00 & 0.11 \\
\hline Manchester & 0.40 & 0.88 & 0.59 & 0.36 & 0.49 & 0.46 & 0.07 & 0.64 & 0.38 & 0.79 \\
\hline London/Oxford & 0.84 & 0.88 & 0.82 & 0.39 & 0.79 & 0.86 & 0.29 & 0.83 & 0.46 & 0.67 \\
\hline Netherlands/Belgium & 0.57 & 0.86 & 0.74 & 0.53 & 0.71 & 0.72 & 0.23 & 0.74 & 0.42 & 0.76 \\
\hline Ruhr_Area & 0.69 & 0.89 & 0.65 & 0.50 & 0.80 & 0.91 & 0.67 & 0.68 & 0.46 & 0.91 \\
\hline Munich/Augsburg & 0.29 & 0.87 & 0.67 & 0.68 & 0.50 & 0.63 & 0.28 & 0.78 & 0.68 & 0.87 \\
\hline Vorarlberg & 0.04 & 0.59 & 0.35 & 0.52 & 0.34 & 0.62 & 0.02 & 0.69 & 0.47 & 0.53 \\
\hline Paris & 0.86 & 0.90 & 0.91 & 0.86 & 0.91 & 0.95 & 0.81 & 0.92 & 0.85 & 0.95 \\
\hline Gyor & 0.02 & 0.65 & 0.12 & 0.21 & 0.31 & 0.73 & 0.24 & 0.46 & 0.41 & 0.76 \\
\hline Lugano & 0.66 & 0.58 & 0.83 & 0.60 & 0.76 & 0.83 & 0.28 & 0.82 & 0.48 & 0.70 \\
\hline Turin & 0.65 & 0.87 & 0.67 & 0.51 & 0.77 & 0.81 & 0.47 & 0.75 & 0.54 & 0.87 \\
\hline Rome & 0.73 & 0.89 & 0.75 & 0.67 & 0.79 & 0.86 & 0.69 & 0.80 & 0.70 & 0.96 \\
\hline Barcelona & 0.90 & 0.91 & 0.69 & 0.32 & 0.94 & 0.80 & 0.40 & 0.74 & 0.35 & 0.83 \\
\hline Catalunya & 0.72 & 0.89 & 0.63 & 0.41 & 0.83 & 0.73 & 0.39 & 0.73 & 0.46 & 0.88 \\
\hline Athens & 0.49 & 0.85 & 0.70 & 0.66 & 0.71 & 0.74 & 0.44 & 0.79 & 0.65 & 0.91 \\
\hline Heraklion & 0.18 & 0.63 & 0.37 & 0.42 & 0.20 & 0.78 & 0.59 & 0.40 & 0.45 & 0.96 \\
\hline Mean & 0.51 & 0.80 & 0.61 & 0.50 & 0.64 & 0.74 & 0.39 & 0.69 & 0.50 & 0.80 \\
\hline Mean North & 0.53 & 0.82 & 0.64 & 0.56 & 0.66 & 0.71 & 0.43 & 0.67 & 0.54 & 0.89 \\
\hline Mean West/Central & 0.44 & 0.77 & 0.59 & 0.47 & 0.58 & 0.72 & 0.31 & 0.69 & 0.46 & 0.71 \\
\hline Mean South & 0.50 & 0.80 & 0.64 & 0.52 & 0.64 & 0.75 & 0.34 & 0.73 & 0.52 & 0.78 \\
\hline
\end{tabular}


Table 5

Median ratios between average concentrations of different components per study area.

\begin{tabular}{|c|c|c|c|c|c|c|c|c|c|c|}
\hline Study_Area & $\mathrm{NO}_{2} / \mathrm{PM}_{2.5}$ & $\begin{array}{l}\mathrm{NO}_{2} / \mathrm{PM}_{2.5} \\
\text { absorbance }\end{array}$ & $\mathrm{NO}_{2} / \mathrm{PM}_{10}$ & $\mathrm{NO}_{2} / \mathrm{PM}_{\text {coarse }}$ & $\begin{array}{l}\mathrm{PM}_{2.5} / \mathrm{PM}_{2.5} \\
\text { absorbance }\end{array}$ & $\mathrm{PM}_{2.5} / \mathrm{PM}_{10}$ & $\mathrm{PM}_{2.5} / \mathrm{PM}_{\text {coarse }}$ & $\begin{array}{l}\mathrm{PM}_{2.5} \\
\text { absorbance/ } \\
\mathrm{PM}_{10}\end{array}$ & $\begin{array}{l}\mathrm{PM}_{2.5} \\
\text { absorbance/ } \\
\mathrm{PM}_{\text {coarse }}\end{array}$ & $\mathrm{PM}_{10} / \mathrm{PM}_{\text {coarse }}$ \\
\hline Oslo & 2.33 & 14.84 & 1.41 & 7.80 & 6.97 & 0.66 & 4.52 & 0.10 & 0.58 & 5.42 \\
\hline Stockholm County & 2.11 & 21.30 & 0.95 & 2.02 & 10.67 & 0.49 & 1.16 & 0.05 & 0.10 & 2.16 \\
\hline Helsinki/Turku & 2.11 & 16.54 & 1.24 & 3.18 & 8.05 & 0.60 & 1.61 & 0.08 & 0.20 & 2.61 \\
\hline Copenhagen & 1.47 & 13.21 & 0.95 & 2.76 & 9.53 & 0.65 & 1.97 & 0.07 & 0.21 & 2.97 \\
\hline Kaunas & 0.77 & 7.87 & 0.54 & 2.11 & 10.72 & 0.72 & 2.87 & 0.07 & 0.26 & 3.87 \\
\hline Manchester & 2.75 & 20.12 & 1.54 & 3.58 & 7.71 & 0.57 & 1.34 & 0.08 & 0.18 & 2.34 \\
\hline London/Oxford & 3.03 & 21.74 & 1.82 & 4.75 & 7.54 & 0.60 & 1.58 & 0.08 & 0.22 & 2.58 \\
\hline Netherlands/Belgium & 1.66 & 17.73 & 1.08 & 3.18 & 11.33 & 0.66 & 1.96 & 0.06 & 0.18 & 2.96 \\
\hline Ruhr_Area & 1.59 & 18.06 & 1.05 & 3.16 & 11.60 & 0.67 & 2.01 & 0.06 & 0.18 & 3.01 \\
\hline Munich/Augsburg & 1.95 & 14.49 & 1.25 & 3.65 & 7.79 & 0.66 & 2.00 & 0.09 & 0.26 & 3.00 \\
\hline Vorarlberg & 1.65 & 11.87 & 1.05 & 3.02 & 7.43 & 0.65 & 1.92 & 0.09 & 0.26 & 2.92 \\
\hline Paris & 1.93 & 15.44 & 1.20 & 3.26 & 8.97 & 0.64 & 1.83 & 0.08 & 0.21 & 2.83 \\
\hline Gyor & 0.67 & 7.73 & 0.49 & 1.92 & 11.92 & 0.74 & 2.96 & 0.06 & 0.25 & 3.95 \\
\hline Lugano & 1.61 & 13.77 & 1.14 & 4.07 & 8.79 & 0.72 & 2.64 & 0.08 & 0.30 & 3.64 \\
\hline Turin & 1.59 & 15.44 & 1.08 & 3.50 & 10.12 & 0.69 & 2.28 & 0.07 & 0.23 & 3.28 \\
\hline Rome & 2.03 & 13.95 & 1.09 & 2.39 & 7.05 & 0.54 & 1.22 & 0.08 & 0.17 & 2.22 \\
\hline Barcelona & 3.06 & 18.68 & 1.34 & 2.42 & 6.24 & 0.44 & 0.78 & 0.07 & 0.13 & 1.78 \\
\hline Catalunya & 2.57 & 16.83 & 1.15 & 2.12 & 7.03 & 0.45 & 0.84 & 0.07 & 0.12 & 1.84 \\
\hline Athens & 1.61 & 14.19 & 0.78 & 1.54 & 9.06 & 0.49 & 0.98 & 0.05 & 0.11 & 1.98 \\
\hline Heraklion & 0.83 & 10.18 & 0.32 & 0.52 & 12.96 & 0.39 & 0.63 & 0.03 & 0.05 & 1.63 \\
\hline Mean & 1.87 & 15.20 & 1.07 & 3.05 & 9.07 & 0.60 & 1.86 & 0.07 & 0.21 & 2.85 \\
\hline Mean North & 2.01 & 16.47 & 1.14 & 3.94 & 8.81 & 0.60 & 2.32 & 0.08 & 0.27 & 3.29 \\
\hline Mean West/Central & 1.76 & 14.88 & 1.12 & 3.27 & 9.38 & 0.66 & 2.11 & 0.08 & 0.23 & 3.11 \\
\hline Mean South & 1.84 & 15.64 & 1.17 & 3.41 & 9.32 & 0.66 & 2.05 & 0.08 & 0.23 & 3.05 \\
\hline
\end{tabular}

volatile components than the continuous monitors typically used in networks in Europe (Putaud et al., 2004; Van Dingenen et al., 2004). We conditioned filters at $37 \% \mathrm{RH}$ before and after weighing following US EPA procedures. Our PM measurements are therefore less affected by particle-bound water than protocols which condition at 50\% RH (Van Dingenen et al., 2004). The Harvard impactor is not a European reference sampler, but has been shown to agree well with reference samplers such as the $\mathrm{PM}_{10}$ High Volume sampler (Hoek et al., 1997). A limitation of our study is that measurements were conducted in two years and hence some of the variability between areas may be affected by different meteorological conditions. To assess this issue, all $\mathrm{PM}_{10}$ and $\mathrm{PM}_{2.5}$ annual average concentrations in AIRBASE in the ESCAPE countries from 2009 to 2010 were evaluated. Only stations with more than $75 \%$ data capture in both years were included in the analysis. Overall, there was no difference in average concentration between 2009 and 2010. The mean (standard deviation) $\mathrm{PM}_{10}$ concentration was 22.4 (5.9) and 22.5 (5.5) $\mu \mathrm{g} \mathrm{m}^{-3}$ in 2009 and 2010 respectively. The mean (standard deviation) $\mathrm{PM}_{2.5}$ concentration was 12.6 (3.5) and $13.3(4.2) \mu \mathrm{g} \mathrm{m}^{-3}$ in 2009 and 2010 respectively. Our temporal coverage of each site was limited to three 2-week samples. We adjusted the averages however with measurements at a reference site which measured for a whole year, to obtain a valid spatial contrast. Because of our focus on assessing human residential exposures, we did not include remote sites to assess the 'natural' background. Regional background sites were in villages, often near cities. Furthermore, street sites were chosen at the façade of homes, not on the kerbside.

\subsection{Concentration contrasts between study areas}

Across the study areas the fraction of regional background, urban background and street sites differed somewhat. Therefore, when comparing concentrations between areas, we focus mostly on comparing the urban background levels. The higher $\mathrm{PM}_{10}$ concentrations in the Southern and Eastern Europe are consistent with previous studies based upon routine monitoring networks
(European Environment Agency (EEA) 2009; Beelen et al., 2009) and specific monitoring campaigns (Van Dingenen et al., 2004; Hoek et al., 1997; Lianou et al., 2011). We also observed some differences with the EEA PM 10 map, e.g. our $\mathrm{PM}_{10}$ concentrations in Kaunas including regional background are substantially higher. This may be due to differences in $\mathrm{PM}_{10}$ sampling equipment between the routine networks in different countries, which limits comparison (European Environment Agency (EEA) 2009). The high $\mathrm{PM}_{10}$ concentrations in the eastern study areas were due to high $\mathrm{PM}_{2.5}$ concentrations (below).

Less information is available from the literature about $\mathrm{PM}_{2.5}$ and $\mathrm{PM}_{2.5}$ absorbance spatial gradients in Europe. We found patterns for $\mathrm{PM}_{2.5}$ and $\mathrm{PM}_{10}$, which broadly agree with a study in 21 areas in Europe, measuring one urban background site per area over an entire year (Götschi et al., 2005; Hazenkamp-von Arx et al., 2004). Both our study and the Hazenkamp-study found high $\mathrm{PM}_{2.5}$ concentrations in Turin. High traffic emissions alone are an unlikely explanation of these high concentrations, as $\mathrm{PM}_{2.5}$ and $\mathrm{PM}_{2.5}$ absorbance concentrations in Turin were substantially higher than those in the larger city of Rome. Turin is located in the Po-valley where specific meteorological conditions in combination with industrial, domestic and traffic emissions may play an important role. Similar patterns across Europe were also found in two smaller studies (Hoek et al., 2002a,b; Puustinen et al., 2007). Concentrations in Eastern Europe have been high in the past because of both industrial emissions and coal combustion (Houthuijs et al., 2001), but have since been reduced significantly (Heinrich et al., 2000). Although we included two moderately sized Eastern European cities, $\mathrm{PM}_{2.5}$ and $\mathrm{PM}_{10}$ concentrations were still relatively high. This probably reflects the influence of large area sources in the region as absorbance levels (reflecting more local sources, particularly traffic) were relatively low - similar to those found in, for example Munich/Augsburg and Netherlands/Belgium.

The spatial gradient of $\mathrm{PM}_{\text {coarse }}$ differs from the $\mathrm{PM}_{2.5}$ gradient, with high $\mathrm{PM}_{\text {coarse }}$ concentrations found in Heraklion, Athens and Barcelona. Turin has much lower levels of PM $_{\text {coarse. The pattern is }}$ likely explained by the dryer climate in these areas, resulting in 
more resuspension of coarse particles. Furthermore, the Mediterranean area is also affected by Sahara dust events (Perez et al., 2008; Zauli Sajani et al., 2011).

\subsection{Spatial variability within study areas}

Spatial variability within study areas was larger than between areas for $\mathrm{PM}_{2.5}$ absorbance and was substantial for all other components. For the ESCAPE project, this is important as the main analyses of associations between air pollution and health will focus on within-study area variability. Overall contrasts (total range/ mean) also depend on the distribution of sites, but we can clearly see that (in all areas) the spatial contrasts in $\mathrm{PM}_{2.5}$ absorbance and $\mathrm{PM}_{\text {coarse }}$ are higher than those for $\mathrm{PM}_{2.5}$ and $\mathrm{PM}_{10}$ (Table 2 ). The overall within area spatial variability is affected by differences in e.g. the number of street sites. All site types were selected to represent characteristic regional background, urban background or street sites for that area, so the ratio between the site types is more comparable between study areas.

\subsection{Street/urban background contrasts}

For all components, we found large variation of the street/urban background ratios between study areas with no clear pattern across Europe. These differences in ratios are probably explained by a combination of differences in actual traffic intensity, traffic composition (percentage diesel fuelled vehicles), local climate and meteorological factors (mixing height, temperature), local geography (mountains, lakes) and street configuration (e.g. street canyons and tree-lined streets). Contrasts between background and street sites in Manchester were lower than those in other areas for all components, because many selected street sites were further away from the road than in the other areas. The implication is that the use of exposure indicators, such as proximity to major roads or traffic intensity on nearby roads, in different study areas is associated with different actual contrasts in exposure. This limits comparison of health effect estimates related to major roadway proximity across studies (Jerrett et al., 2005a). A further discussion is found in the companion paper (Cyrys et al., 2012).

As has been reported previously (Janssen et al., 2011), we found that ratios between traffic and urban background sites were consistently lower for $\mathrm{PM}_{2.5}$ than for $\mathrm{PM}_{2.5}$ absorbance. This is likely due to the high background concentrations of fine particles related to long-range transported air pollution. $\mathrm{PM}_{2.5}$ absorbance characterizes local soot emissions, especially from diesel vehicles and other combustion sources such as residential wood combustion. The traffic/urban background ratio for $\mathrm{PM}_{\text {coarse }}$ was similar to that of absorbance, illustrating the importance of non-tailpipe emissions (Johansson et al., 2009; Gietl and Klemm, 2009). Non-tailpipe emissions are due to resuspended dust from road surface material and wear of brakes, clutch and tyres. In Northern Europe, the sanding of icy roads and the use of studded tyres further increase non-tailpipe emissions. Traffic/urban background ratios were high in all areas, with a tendency towards higher ratios in the Northern European areas (e.g. Stockholm County).

\subsection{Correlation between components}

We found very high correlations of the spatial variation within areas between $\mathrm{PM}_{2.5}$ and $\mathrm{PM}_{10}$, and between $\mathrm{NO}_{2}, \mathrm{NO}_{x} \& \mathrm{PM}_{2.5}$ absorbance in most of the study areas. The implication is that in studies that assess the relationship between spatial variation of long-term average air pollution and health, the health effects of these components cannot be separated from each other within a single study area. However, as the ratio of these components varied significantly across Europe, within the ESCAPE study we will be able to make use of the difference in composition of the mixture to assess health effects of different components. Furthermore, the correlation between $\mathrm{PM}_{2.5}$ and $\mathrm{PM}_{\text {coarse }}$ was substantially lower in most areas, probably allowing separation of these components. The high correlation between $\mathrm{NO}_{2}$ and absorbance agrees with results from the TRAPCA study, carried out in 1999-2000 (Lewné et al., 2004). In TRAPCA, the correlation $\left(R^{2}\right)$ between $\mathrm{NO}_{2}$ and $\mathrm{PM}_{2.5}$ absorbance for Munich, Netherlands and Stockholm was 0.76, 0.86 and 0.81 respectively. These correlations remained largely unchanged in ESCAPE, now with $R^{2}$ values of $0.87,0.86$ and 0.84 for Munich/Augsburg, Netherlands/Belgium and Stockholm County, respectively.

Correlations $\left(R^{2}\right)$ between annual average concentrations of $\mathrm{NO}_{2}$ and $\mathrm{PM}_{2.5}$ were, however, more variable than reported within TRAPCA. Good correlations $\left(R^{2}\right)$ between $\mathrm{NO}_{2}$ and $\mathrm{PM}_{2.5}$ were previously found in TRAPCA for all three areas $0.71,0.80$ and 0.64 (Lewné et al., 2004), while in ESCAPE the $R^{2}$ values for Munich and the Netherlands dropped to 0.29 and 0.57 respectively, while Stockholm remained stable at 0.64 . The three study areas were larger in ESCAPE than in TRAPCA, which may affect the comparison, as well as changes over time in fleet composition, traffic intensity and emission rates. Many epidemiological studies on traffic have used $\mathrm{NO}_{2}$ as a general indicator for traffic-related air pollution (HEI, 2010), but the highly variable correlations and concentration ratios between $\mathrm{NO}_{2}$ and other metrics suggest that $\mathrm{NO}_{2}$ might be a better general traffic indicator in some areas (Paris, Barcelona) than in others (Kaunas, Lugano, Vorarlberg).

\section{Conclusion}

We found clear spatial contrasts between $\mathrm{PM}_{2.5}, \mathrm{PM}_{2.5}$ absorbance, $\mathrm{PM}_{10}$ and $\mathrm{PM}_{\text {coarse, }}$ both within and between the 20 study areas. While there were large differences in background concentration between areas for all components, within-area contrasts were particularly clear for $\mathrm{PM}_{2.5}$ absorbance and $\mathrm{PM}_{\text {coarse. Signifi- }}$ cant differences were found between urban background sites and street sites for most study areas. High street/background ratios for $\mathrm{PM}_{\text {coarse }}$ specifically indicate the importance of non-tailpipe emissions. The highly standardized measurement of particle concentrations across Europe in ESCAPE will contribute to a consistent assessment of health effects across Europe.

\section{Competing interest}

The authors declare they have no competing financial interest.

\section{Acknowledgements}

We thank Meng Wang, Marjan Tewis and Geert de Vrieze (IRAS, Utrecht University, The Netherlands) for their help in filter weighing, reflection measurements and data management. Furthermore, we thank all those who were responsible for air pollution measurements, data management and project supervision in all study areas: Haytham Alhamwi, Sònia Alvarez, Giovanna Berti, Laura Bouso, Simone Bucci, Ennio Cadum, Glòria Carrasco, Guido Fischer, Francesco Forastiere, Marco Gilardetti, Erwan Gremaud, Jianwei Gu, Stephanie von Klot, Nino Künzli, Thomas Kusch, Sally Liu, Francesco Lollobrigida, Jaume Matamala, Alwin Muxel, Patrizio Pasquinelli, Mike Pitz, Meritxell Portella, Daniela Raffaele, Anna Ripoll, Nuthchyawach Sanguanchaiyakrit, Jordi Sunyer, Pekka Taimisto, Francesco Troiano, Tarja Yli-Tuomi, Eleonora Zirro.

The research leading to these results has received funding from the European Community's Seventh Framework Program (FP7/ 2007-2011) under grant agreement number: 211250. Also with 
support of the Swiss Federal Office for the Environment (FOEN) and SNSF Grant 324730_135673.

\section{Appendix A. Supplementary data}

Supplementary data related to this article can be found at http:// dx.doi.org/10.1016/j.atmosenv.2012.08.038.

\section{References}

Beelen, R., Hoek, G., Pebesma, E., Vienneau, D., de Hoogh, K., Briggs, D.J., 2009 Mapping of background air pollution at a fine spatial scale across the European Union. The Science of the Total Environment 407, 1852-1867.

Beelen, R., Hoek, G., van den Brandt, P.A., Goldbohm, R.A., Fischer, P., Schouten, L.J., Armstrong, B., Brunekreef, B., 2008. Long-term exposure to traffic-related air pollution and lung cancer risk. Epidemiology (Cambridge, Mass.) 19, 702-710.

Beelen, R., Hoek, G., Fischer, P., Brandt, P.A.v.d., Brunekreef, B., 2007. Estimated longterm outdoor air pollution concentrations in a cohort study. Atmospheric Environment 41, 1343-1358.

Brunekreef, B., Janssen, N., de Hartog, J., Oldenwening, M., Meliefste, K., Hoek, G. Lanki, T., Timonen, K., Vallius, M., Pekkanen, J., Van Grieken, R., 2005. Personal, Indoor, and Outdoor Exposures to PM2.5 and its Components for Groups of Cardiovascular Patients in Amsterdam and Helsinki. Research Report (Health Effects Institute), pp. 1-70, discussion 71-79.

Brunekreef, B., Forsberg, B., 2005. Epidemiological evidence of effects of coarse airborne particles on health. The European Respiratory Journal: Official Journal of the European Society for Clinical Respiratory Physiology 26, 309-318.

Brunekreef, B., Holgate, S.T., 2002. Air pollution and health. Lancet 360, 1233-1242.

Brunekreef, B., Maynard, R.L., 2008. A note on the $2008 \mathrm{EU}$ standards for particulate matter. Atmospheric Environment 42, 6425-6430.

Cyrys, J., Stölzel, M., Heinrich, J., Kreyling, W.G., Menzel, N., Wittmaack, K., Tuch, T. Wichmann, H., 2003. Elemental composition and sources of fine and ultrafine ambient particles in Erfurt, Germany. Science of the Total Environment 305 $143-156$

Cyrys, J., Eeftens, M., Heinrich, J., Ampe, C., Armengaud, A., Beelen, R., Bellander, T., Beregszaszi, T., Birk, M., Cesaroni, G., Cirach, M., de Hoogh, K., De Nazelle, A., de Vocht, F., Declercq, C., Dèdelè, A., Dimakopoulou, K., Eriksen, K., Galassi, C., Gražulevičienè, R., Grivas, G., Gruzieva, O., Hagenbjörk Gustafsson, A Hoffmann, B., Ineichen, A., Krämer, U., Lanki, T., Lozano, P., Madsen, C. Meliefste, K., Iakovides, M., Modig, L., Mölter, A., Mosler, G., Nieuwenhuijsen, M. Nonnemacher $M$, Oldenwening $M$, Pontet, $S$, Probst-Hensch, $N$, Quass, $U$, Raaschou-Nielsen, O., Peters, A., Ranzi, A., Sugiri, D., Taimisto, P., Tsai, M. Tziaras, T., VasköviÉ., Villani, S., Wang, M., Brunekreef, B., Hoek, G., 2012. Variation of $\mathrm{NO}_{2}$ and $\mathrm{NO}_{x}$ concentrations between and within 36 European study areas: results from the ESCAPE study. Atmospheric Environment 62, 374-390.

Dockery, D.W., Pope, C.A., Xu, X., Spengler, J.D., Ware, J.H., Fay, M.E., Ferris, B.G. Speizer, F.E., 1993. An association between air pollution and mortality in six U.S. cities. The New England Journal of Medicine 329, 1753-1759.

European Environment Agency (EEA), 2009. Spatial Assessment of $\mathrm{PM}_{10}$ and Ozone Concentrations in Europe (2005).

Gietl, J.K., Klemm, O., 2009. Analysis of traffic and meteorology on airborne particulate matter in Munster, northwest Germany. Journal of the Air \& Waste Management Association (1995) 59, 809-818.

Götschi, T., Hazenkamp-von Arx, M.E., Heinrich, J., Bono, R., Burney, P., Forsberg, B. Jarvis, D., Maldonado, J. Norbäck, D. Stern, W.B., Sunyer, J., Torén, K. Verlato, G., Villani, S., Künzli, N., 2005. Elemental composition and reflectance of ambient fine particles at 21 European locations. Atmospheric Environment 39, 5947-5958.

Hazenkamp-von Arx, M.E., Götschi, T., Ackermann-Liebrich, U., Bono, R., Burney, P., Cyrys, J., Jarvis, D., Lillienberg, L., Luczynska, C., Maldonado, J.A., Jaén, A., de Marco, R., Mi, Y., Modig, L., Bayer-Oglesby, L., Payo, F., Soon, A., Sunyer, J., Villani, S., Weyler, J., Künzli, N., 2004. $\mathrm{PM}_{2.5}$ and $\mathrm{NO}_{2}$ assessment in 21 European Study Centres of ECRHS II: annual means and seasonal differences. Atmospheric Environment 38, 1943-1953.

HEI, 2010. Report 17: Traffic-related Air Pollution: a Critical Review of the Literature on Emissions, Exposure, and Health Effects.

Heinrich, J., Hoelscher, B., Wichmann, H.E., 2000. Decline of ambient air pollution and respiratory symptoms in children. American Journal of Respiratory and Critical Care Medicine 161, 1930-1936.

Hoek, G., Beelen, R., de Hoogh, K., Vienneau, D., Gulliver, J., Fischer, P., Briggs, D. 2008. A review of land-use regression models to assess spatial variation of outdoor air pollution. Atmospheric Environment 42, 7561-7578.

Hoek, G., Brunekreef, B., Goldbohm, S., Fischer, P., van den Brandt, P.A., 2002a. Association between mortality and indicators of traffic-related air pollution in the Netherlands: a cohort study. The Lancet 360, 1203-1209.

Hoek, G., Meliefste, K., Cyrys, J., Lewné, M., Bellander, T., Brauer, M., Fischer, P., Gehring, U., Heinrich, J., van Vliet, P., Brunekreef, B., 2002b. Spatial variability of fine particle concentrations in three European areas. Atmospheric Environment 36, 4077-4088.

Hoek, G., Forsberg, B., Borowska, M., Hlawiczka, S., Vaskövi, E., Welinder, H., Branis, M., Benes, I., Kotesovec, F., Otto Hagen, L., Cyrys, J., Jantunen, M. Roemer, W., Brunekreef, B., 1997. Wintertime $\mathrm{PM}_{10}$ and black smoke concentrations across Europe: results from the peace study. Atmospheric Environment 31, 3609-3622.

Houthuijs, D., Breugelmans, O., Hoek, G., Vaskövi, É., Miháliková, E., Pastuszka, J.S. Jirik, V., Sachelarescu, S., Lolova, D., Meliefste, K., Uzunova, E., Marinescu, C., Volf, J., de Leeuw, F., van de Wiel, H., Fletcher, T., Lebret, E., Brunekreef, B., 2001. $\mathrm{PM}_{10}$ and $\mathrm{PM}_{25}$ concentrations in central and eastern Europe: results from the Cesar study. Atmospheric Environment 35, 2757-2771.

ISO (International Standardization Organization), 1993. ISO 9835: Ambient Air Determination of a Black Smoke Index.

Janssen, N., Hoek, G., Simic-Lawson, M., Fischer, P., van Bree, L., ten Brink, H., Keuken, M., Atkinson, R.W., Anderson, H.R., Brunekreef, B., Cassee, F.R., 2011. Black carbon as an additional indicator of the adverse health effects of airborne particles compared with $\mathrm{PM}_{10}$ and $\mathrm{PM}_{2.5}$. Environmental Health Perspectives 119, 1691-1699.

Jerrett, M., Arain, A., Kanaroglou, P., Beckerman, B., Potoglou, D., Sahsuvaroglu, T., Morrison, J., Giovis, C., 2005a. A review and evaluation of intraurban air pollution exposure models. Journal of Exposure Analysis and Environmental Epidemiology 15, 185-204.

Jerrett, M., Burnett, R.T., Ma, R., Pope 3rd, C.A., Krewski, D., Newbold, K.B., Thurston, G., Shi, Y., Finkelstein, N., Calle, E.E., Thun, M.J., 2005b. Spatial analysis of air pollution and mortality in Los Angeles. Epidemiology (Cambridge, Mass.) $16,727-736$.

Johansson, C., Norman, M., Burman, L., 2009. Road traffic emission factors for heavy metals. Atmospheric Environment 43, 4681-4688.

Künzli, N., Kaiser, R., Medina, S., Studnicka, M., Chanel, O., Filliger, P., Herry, M., Horak Jr., F., Puybonnieux-Texier, V., Quénel, P., Schneider, J., Seethaler, R., Vergnaud, J., Sommer, H., 2000. Public-health impact of outdoor and trafficrelated air pollution: a European assessment. The Lancet 356, 795-801.

Lewné, M., Cyrys, J., Meliefste, K., Hoek, G., Brauer, M., Fischer, P., Gehring, U., Heinrich, J., Brunekreef, B., Bellander, T., 2004. Spatial variation in nitrogen dioxide in three European areas. Science of the Total Environment 332 217-230.

Lianou, M., Chalbot, M.C., Kavouras, I.G., Kotronarou, A., Karakatsani, A., Analytis, A., Katsouyanni, K., Puustinen, A., Hameri, K., Vallius, M., Pekkanen, J., Meddings, C., Harrison, R.M., Ayres, J.G., ten Brick, H., Kos, G., Meliefste, K., de Hartog, J., Hoek, G., 2011. Temporal variations of atmospheric aerosol in four European urban areas. Environmental Science and Pollution Research International $18,1202-1212$

Monn, C., 2001. Exposure assessment of air pollutants: a review on spatial heterogeneity and indoor/outdoor/personal exposure to suspended particulate matter, nitrogen dioxide and ozone. Atmospheric Environment 35, 1-32.

Morgenstern, V., Zutavern, A., Cyrys, J., Brockow, I., Gehring, U., Koletzko, S., Bauer, C.P., Reinhardt, D., Wichmann, H., Heinrich, J., 2007. Respiratory health and individual estimated exposure to traffic-related air pollutants in a cohort of young children. Occupational and Environmental Medicine 64, 8-16.

Perez, L., Tobias, A., Querol, X., Kunzli, N., Pey, J., Alastuey, A., Viana, M., Valero, N., Gonzalez-Cabre, M., Sunyer, J., 2008. Coarse particles from Saharan dust and daily mortality. Epidemiology (Cambridge, Mass.) 19, 800-807.

Pope 3rd, C.A., Dockery, D.W., 2006. Health effects of fine particulate air pollution: lines that connect. Journal of the Air \& Waste Management Association (1995) 56, 709-742.

Pope 3rd, C.A., Burnett, R.T., Thun, M.J., Calle, E.E., Krewski, D., Ito, K., Thurston, G.D., 2002. Lung cancer, cardiopulmonary mortality, and long-term exposure to fine particulate air pollution. JAMA: The Journal of the American Medical Association 287, 1132-1141.

Putaud, J., Raes, F., Van Dingenen, R., Brüggemann, E., Facchini, M., Decesari, S., Fuzzi, S., Gehrig, R., Hüglin, C., Laj, P., Lorbeer, G., Maenhaut, W., Mihalopoulos, N., Müller, K., Querol, X., Rodriguez, S., Schneider, J., Spindler, G., Brink, H.t., Tørseth, K., Wiedensohler, A., 2004. A European aerosol phenomenology-2: chemical characteristics of particulate matter at kerbside, urban, rural and background sites in Europe. Atmospheric Environment 38, 2579-2595.

Puustinen, A., Hämeri, K., Pekkanen, J., Kulmara, M., de Hartog, J., Meliefste, K., ten Brink, H., Kos, G., Katsouyanni, K., Karakatsani, A., Kotronarou, A., Kavouras, I., Meddings, C., Thomas, S., Harrison, R., Ayres, J., van der Zee, S., Hoek, G., 2007. Spatial variation of particle number and mass over four European cities. Atmospheric Environment 31, 6622-6636.

Rückerl, R., Schneider, A., Breitner, S., Cyrys, J., Peters, A., 2011. Health effects of particulate air pollution: a review of epidemiological evidence. Inhalation Toxicology 23, 555-592.

Van Dingenen, R., Raes, F., Putaud, J., Baltensperger, U., Charron, A., Facchini, M.-., Decesari, S., Fuzzi, S., Gehrig, R., Hansson, H., Harrison, R.M., Hüglin, C., Jones, A.M., Laj, P., Lorbeer, G., Maenhaut, W., Palmgren, F., Querol, X., Rodriguez, S., Schneider, J., Brink, H.t., Tunved, P., Tørseth, K., Wehner, B. Weingartner, E., Wiedensohler, A., Wåhlin, P., 2004. A European aerosol phenomenology-1: physical characteristics of particulate matter at kerbside, urban, rural and background sites in Europe. Atmospheric Environment 38, 2561-2577.

Velders, G.J.M., Diederen, H.S.M.A., 2009. Likelihood of meeting the EU limit values for $\mathrm{NO}_{2}$ and $\mathrm{PM}_{10}$ concentrations in the Netherlands. Atmospheric Environment 43, 3060-3069.

WHO, 2006. Air Quality Guidelines. Global update 2005

Zauli Sajani, S., Miglio, R., Bonasoni, P., Cristofanelli, P., Marinoni, A., Sartini, C., Goldoni, C.A., De Girolamo, G., Lauriola, P., 2011. Saharan dust and daily mortality in Emilia-Romagna (Italy). Occupational and Environmental Medicine $68,446-451$. 